\title{
A stratospheric intrusion at the subtropical jet over the Mediterranean Sea: air-borne remote sensing observations and model results
}

\author{
K. Weigel ${ }^{1, *}$, L. Hoffmann ${ }^{1,{ }^{* *}}$, G. Günther ${ }^{1}$, F. Khosrawi ${ }^{2}$, F. Olschewski ${ }^{3}$, P. Preusse ${ }^{1}$, R. Spang ${ }^{1}$, F. Stroh ${ }^{1}$, and \\ M. Riese ${ }^{1,3}$ \\ ${ }^{1}$ Institute of Energy and Climate Research (IEK-7), Forschungszentrum Jülich, 52425 Jülich, Germany \\ ${ }^{2}$ Department of Meteorology, Stockholm University, 10691 Stockholm, Sweden \\ ${ }^{3}$ Department of Physics, University of Wuppertal, 42907 Wuppertal, Germany \\ * now at: Institute of Environmental Physics (IUP), University of Bremen, 28359 Bremen, Germany \\ ** now at: Juelich Supercomputing Centre (JSC), Forschungszentrum Jülich, 52425 Jülich, Germany
}

Correspondence to: K. Weigel (weigel@iup.physik.uni-bremen.de)

Received: 2 February 2012 - Published in Atmos. Chem. Phys. Discuss.: 20 March 2012

Revised: 24 August 2012 - Accepted: 30 August 2012 - Published: 20 September 2012

\begin{abstract}
Remote sensing measurements from the Cryogenic Infrared Spectrometers and Telescope for the Atmosphere - New Frontiers (CRISTA-NF) during a flight on 29 July 2006 are presented. This flight is part of the AMMASCOUT-O3 measurement campaign, where CRISTA-NF was deployed on the high-flying research aircraft M55Geophysica. The flight path was located over Italy and the Mediterranean Sea and crossed over the subtropical jet twice. Measurements of temperature, and the volume mixing ratios of water vapor $\left(\mathrm{H}_{2} \mathrm{O}\right)$, ozone $\left(\mathrm{O}_{3}\right)$, nitric acid $\left(\mathrm{HNO}_{3}\right)$ and peroxyacetyl nitrate (PAN) are available with a vertical resolution of up to $500 \mathrm{~m}$ between about 6 to $21 \mathrm{~km}$ altitude. CRISTA-NF observes these trace gases simultaneously and provides a quasi-2-D view of the transition region between the troposphere and the stratosphere. The observation of these different trace gases allows to determine tropospheric and stratospheric air masses. As expected, higher abundances are found where the main source of the trace gases is located: in the stratosphere for $\mathrm{O}_{3}$ and in the troposphere for $\mathrm{H}_{2} \mathrm{O}$ and PAN. Tracer-tracer correlations between $\mathrm{O}_{3}$ and PAN are used to identify the mixed tropospheric and lowermost stratospheric air at the subtropical jet and around the thermal tropopause north of the jet. An intrusion of stratospheric air into the troposphere associated with the subtropical jet is found in the CRISTA-NF observations. The observations indicate that the intrusion is connected to a tropopause fold
\end{abstract}

which is not resolved in the ECMWF analysis data. The intrusion was reproduced in a simulation with the Chemical Lagrangian Model of the Stratosphere (CLaMS). The CLaMS simulation shows, that the lowermost stratospheric air masses in the intrusion where transported along the the subtropical jet. The tropospheric air masses around the intrusion originate from the vicinity of the Asian monsoon anticyclone. This work discusses the nature of the observed processes at the subtropical jet based on the CRISTA-NF observations and the CLaMS simulation.

\section{Introduction}

The Upper Troposphere, Lower Stratosphere (UTLS) is an atmospheric layer where strong gradients of e.g. trace gases and wind speeds exist both vertically and horizontally. Therefore high resolution measurements are important for the understanding of the UTLS (e.g. Gettelman et al., 2011). Nevertheless, small and mesoscale structures and dynamical processes can seldom be observed in detail. In situ measurements require extensive planning and need to rely on forecasts (e.g. Pan et al., 2007). Satellites can only resolve the structures with a large horizontal and vertical extent, i.e. a lower stratospheric intrusion was observed by HIRDLS (Olsen et al., 2008). The regular observation of tropopause 
folds and stratospheric intrusions is not viable for today's satellites (e.g. Tang and Prather, 2012).

During the African Monsoon Multidisciplinary Analysis (AMMA) campaign (Redelsperger et al., 2006; Cairo et al., 2010), the CRyogenic Infrared Spectrometers and Telescope for the Atmosphere - New Frontiers (CRISTA-NF) was deployed on the high altitude aircraft M55-Geophysica (Stefanutti et al., 1999) which can reach a flight level of about $20 \mathrm{~km}$. CRISTA-NF provides information about stratospheric and tropospheric trace gases with a vertical resolution of up to $500 \mathrm{~m}$ using the trace gas retrieval setup presented in Weigel et al. (2010). This enables the instrument CRISTA$\mathrm{NF}$ to distinguish tropospheric and stratospheric air masses and to identify transport and mixing among them and hence, analyses of processes in the UTLS like e.g. blocking anticyclones or tropopause folds. This work presents CRISTANF measurements of $\mathrm{H}_{2} \mathrm{O}, \mathrm{O}_{3}, \mathrm{PAN}, \mathrm{HNO}_{3}$, and temperature during the AMMA-SCOUT- $\mathrm{O}_{3}$ flight on 29 July 2006. These measurements indicate an intrusion of stratospheric air into the troposphere with a horizontal extent of few degree latitude.

CRISTA-NF observed structures in the distribution of trace gases in the vicinity of the subtropical jet. The jet itself inhibits horizontal transport but mixing is common in the regions around the jet (e.g. Gettelman et al., 2011, Manney et al., 2012). Cross-tropopause transport has also been observed above the Mediterranean (e.g. Traub et al., 2003). Intrusions and tropopause folds are often observed in connection with the jet streams and possibly give an important contribution to the stratosphere-troposphere exchange (STE), (see e.g. Shapiro, 1980, Kentarchos et al., 1999; Seo et al., 2008; Olsen et al., 2008). Hoor et al. (2002) observed a greater depth of the mixing layer above the extra-tropical tropopause during summer and explained it with transport across the tropopause at the subtropical jet. Stratospheric intrusions can even effect the $\mathrm{O}_{3}$ mixing ratios at the ground, see e.g., Gerasopoulos et al. (2006) and (Akritidis et al., 2010). These studies present cases, when increased $\mathrm{O}_{3}$ mixing ratios over the Mediterranean (Northern Greece and Athens, respectively) were caused by a stratospheric intrusions.

Due to the high resolution of the CRISTA-NF measurements tracer-tracer correlations are applicable to the measurements to identify mixing processes. Tracer-tracer correlations are a common way to analyze the exchange processes between troposphere and stratosphere for in situ measurements and model simulations (e.g. Pan et al., 2004; James and Legras, 2007).

Another method to learn more about the nature of processes in the atmosphere are model simulations. Therefore, we use results from the Chemical Lagrangian Model of the Stratosphere (CLaMS; McKenna et al., 2002a,b). Lagrangian models are well suited to describe mesoscale processes. Backward trajectories allow an analysis of possible sources of trace gases and their long range transport. With the CRISTA-NF measurements and trajectories from the CLaMS simulation, we investigated the origin of air masses over the Mediterranean at the subtropical jet. Intercontinental transport and transport from Asia determines the pollution in the free and upper troposphere over the Mediterranean (Lelieveld et al., 2002). The Asian monsoon anticyclone has a large influence on the transport in the upper troposphere of the Northern Hemisphere during summer. Non solvable trace gases originating from the Asian monsoon anticyclone can be transported towards the Mediterranean (e.g. Lawrence and Lelieveld, 2010) and have been even observed in the arctic tropopause region (Roiger et al., 2011).

Structures seen in the trace gas distributions retrieved from CRISTA-NF measurements are compared to CLaMS model calculations and European Centre for Medium-Range Weather Forecasts (ECMWF) analysis data. The aim of this study is to show the ability of CRISTA-NF to resolve mesoscale structures and to analyze the observed intrusion of stratospheric air into the troposphere and discuss the origin of the air masses. In Sect. 2 the CRISTA-NF instrument and the CLaMS model are described, Sect. 3 presents the observed trace gases in comparison to the model results and Sect. 4 discusses the observed structures and probable processes causing them as well as the origin of the observed trace gases.

\section{Methods}

\subsection{The CRISTA-NF instrument}

CRISTA-NF contains two mid infrared helium-cooled EbertFastie grating spectrometer (Fastie, 1991) and a limbviewing telescope. This optical system was originally part of the Space Shuttle experiment CRISTA (Offermann et al., 1999; Grossmann et al., 2002). During its two Space Shuttle missions, CRISTA detected numerous small and mediumscale transport and mixing structures in stratospheric trace gas distributions associated with the exchange of tropical and extra-tropical air masses (e.g. Riese et al., 1999, 2002). The aircraft version CRISTA-NF was deployed on the high-flying research aircraft M55-Geophysica (Stefanutti et al., 1999) during the SCOUT-O ${ }_{3}$, AMMA-SCOUT-O ${ }_{3}$, and RECONCILE measurement campaigns (e.g. Spang et al., 2008; Hoffmann et al., 2009; Weigel et al., 2010; Ungermann et al., 2012). Within these campaigns the role of CRISTA-NF was to provide vertically resolved informations about trace gases and clouds in the UTLS. The aim of the European project SCOUT-O3 is to improve the understanding of stratospheric chemistry and its link to climate change, objectives of the SCOUT-O3 campaign at Darwin where to study trace gas transport and dehydration in the tropical tropopause layer (Brunner et al., 2009). AMMA is aimed at the investigation of the West African monsoon (Redelsperger et al., 2006). CRISTA-NF took part as part of the AMMA SCOUT-O3 campaign based in Ouagadougou, Burkina Faso. The test 
flight and the transfer to Ougadougou started from Verona. The results presented here where observed during the test flight.

The helium cooled detectors and spectrometers allow a high signal to noise ratio and fast measurements. Due to the narrow vertical field of view of CRISTA-NF, about $300 \mathrm{~m}$ at tangent height of $10 \mathrm{~km}$, see Spang et al. (2008) and a good vertical resolution of the retrieved trace gas profiles (usually between $0.5 \mathrm{~km}$ and about $5 \mathrm{~km}$ below aircraft altitude dependent on trace gas and height), tracer-tracer correlations are applicable for the retrieval results to identify mixing. One profile is measured in approximately $90 \mathrm{~s}$ corresponding to a horizontal distance of about $15 \mathrm{~km}$ along the flight track (Kullmann et al., 2004). A detailed description of the instrument can be found in Kullmann et al. (2004) the radiometric calibrations are explained in Schroeder et al. (2009).

The line of sight (LOS) points are located at the starebordside of the aircraft. Most information originates from the tangent altitude, which is the altitude where the LOS is closest to the earth surface. Various satellite instruments use a similar observation geometry to retrieve profiles of atmospheric trace gases, e.g. MLS (Microwave Limb Sounder; see e.g. Waters et al., 2006) on Aura and MIPAS (Michelson Interferometer for Passive Atmospheric Sounding; see e.g. Fischer and Oelhaf, 1991) and SCIAMACHY (Scanning Imaging Absorption Spectrometer for Atmospheric CHartographY; see e.g. Bovensmann et al., 1999) on Envisat.

In the measurement mode used during the AMMASCOUT-O ${ }_{3}$ campaign, an elevation mirror points the LOS to 60 different altitudes. This results in a profile of 60 measured spectra. These spectra can be used for the trace gas retrieval if they are located between the aircrafts flight level and about $6 \mathrm{~km}$ above the ground. The profiles lie on a slant in the atmosphere. This observation geometry with its high vertical sampling allows to retrieve data with a high vertical resolution aligned in a quasi-2-D field. During the flight on the 29 July 2006 an active automated pointing stabilization was tested for the first time. It increased the pointing stability during each spectrum and produced more uniform vertical distances within each profile. This improved the data quality significantly compared to the data presented in Hoffmann et al. (2009) and Weigel et al. (2010).

The JUelich Rapid Spectral Simulation Code (JURASSIC) (Hoffmann, 2006) is used to retrieve the composition of the atmosphere. The retrieval algorithm used is based on the optimal estimation maximum a posteriori approach, see Rodgers (2000). JURASSIC was applied previously for the retrieval of data from several satellites (Hoffmann et al., 2008; Hoffmann and Alexander, 2009) and CRISTA-NF (Hoffmann et al., 2009; Weigel et al., 2010). The retrieval setup used allows to retrieve altitude, temperature, and the volume mixing ratios of water vapor $\left(\mathrm{H}_{2} \mathrm{O}\right)$, ozone $\left(\mathrm{O}_{3}\right)$, nitric acid $\left(\mathrm{HNO}_{3}\right)$, peroxyacetyl nitrate (PAN), carbon tetrachloride $\left(\mathrm{CCl}_{4}\right)$ as well as aerosol extinction and a radiometric offset. The setup is explained in detail in Weigel et al.
(2010), where a tropical CRISTA-NF flight was discussed. Because the flight presented here took place in the extratropics at about $40^{\circ} \mathrm{N}$, the mid latitude value from the climatology of Remedios et al. (2007) is used for most trace gases. This differs from Weigel et al. (2010), where the tropical value from the climatology was used as a priori or fixed value for several trace gases and Atmospheric Chemistry Experiment - Fourier Transform Spectrometer (ACE-FTS) data were used as fixed value for HCFC-22. For the setup used here, reliable informations about CFC- 11 and CFC-12 are important for the altitude and temperature retrieval. As in Weigel et al. (2010), CFC-11 and CFC-12 profiles measured on the current flight by the High Altitude Gas Analyser (HAGAR) instrument (see e.g. Werner et al., 2010 and Homan et al., 2010) are combined with climatological mixing ratios from Remedios et al. (2007). The a priori profiles for $\mathrm{O}_{3}$ and temperature, and informations about wind speed and potential vorticity are taken from interpolated ECMWF operational analysis data with 0.5 degrees horizontal resolution on 28 pressure levels interpolated on the retrieval grid and position for each profile.

Spectra with optical dense conditions need to be excluded from the retrieval. Optical dense conditions are defined by the cloud index (CI), the ratio of the mean radiances at 791793 and $830-832 \mathrm{~cm}^{-1}$, (Spang et al., 2008). When the CI is lower than the threshold value of 3.5 no retrieval is done. In most cases optical dense conditions are caused by clouds. To determine the CI no radiative transfer model is necessary. The tangent point position of each spectra and hence CI is roughly known through the geometric pointing information from the instrument and aircraft but is additionally influenced by refraction and an altitude offset caused by pointing uncertainties of the instrument. This needs to be corrected to get the exact vertical position for tangent points of spectra with optical dense conditions. For the trace gas profiles, these corrections are part of the retrieval and are automatically considered.

All CRISTA-NF retrieval results shown are filtered for data quality. To assess the quality of the retrieved data the measurements contribution, the $\chi^{2} \mathrm{~m}^{-1}$ values, and the resolution are calculated as described in Weigel et al. (2010). The normalized $\chi^{2}$ value is a measure for the quality of the radiance fit. The data are filtered for $\chi^{2} \mathrm{~m}^{-1}<2$, excluding profiles where the radiance fit was less good than expected according to the measurement noise. Another measure for the quality of the retrieval is the measurement contribution. It approximates contribution of the measurement relative to the contribution of the a priori values to the retrieval result. All CRISTA-NF results shown are filtered for measurement contribution between 0.8 and 1.2 to exclude profiles with high influence from the a priori data. The vertical resolution, calculated as inverse of the information content (Purser and Huang, 1993), was required to be better than $5 \mathrm{~km}$. Fewer data were analyzed during the dive because of increased aircraft movements and hence decreased data 
quality (causing the white areas in the middle of the retrieval results in Figs. 3-5).

\subsection{The CLaMS model}

Data from the Chemical Lagrangian Model of the Stratosphere (CLaMS; McKenna et al., 2002a,b) have been compared to the CRISTA-NF observations. CLaMS has been employed to analyze the dynamical and chemical processes in the stratosphere and their influence on stratospheric trace gases. Several studies demonstrated the capability of CLaMS by comparing the simulation results to remote sensing measurements, among them the space shuttle experiment CRyogenic Infrared Spectrometers and Telescopes for the Atmosphere (CRISTA) (e.g. Khosrawi et al., 2005) and the Michelson Interferometer for Passive Atmospheric Sounding (MIPAS) (e.g. Vogel et al., 2008) and in situ data (e.g. Günther et al., 2008).

The introduction of a hybrid vertical coordinate $(\zeta$ coordinates, see Konopka et al., 2007) extended the range of application for CLaMS to the tropopause region and troposphere where most of the CRISTA-NF measurements are located. The $\zeta$-coordinates are a combination of the potential temperature in the stratosphere and the pressure in the troposphere.

The CLaMS model run used in this study is a two month transient global run, embedded in a climatological run following Konopka et al. (2007) using the HALOE climatology developed by Grooß and Russell (2005) for initialization and boundary conditions for most trace gases. For $\mathrm{H}_{2} \mathrm{O}$, ECMWF analysis data are used for initialization and boundary conditions. The lower and upper boundaries are set to $\zeta=200 \mathrm{~K}$ and $\zeta=500 \mathrm{~K}$, respectively. Condensation and freezing are based on cloud parameters by Krämer et al. (2008) and Schiller et al. (2008). The horizontal resolution is $70 \mathrm{~km}$ between 20 and $40^{\circ} \mathrm{N}$ and $100 \mathrm{~km}$ north and south of this latitude range. CLaMS was run with a temporal resolution of $6 \mathrm{~h}$ and a Lyapunov exponent of 1.5. To adjust the time between CRISTA-NF observations and CLaMS fields a correction based on the CLaMS trajectories is used.

Since the vertical resolution of CLaMS is partly better than the vertical resolution of CRISTA-NF, CLaMS data are interpolated onto the CRISTA-NF grid and their resolution is degraded with the Averaging Kernel (AVK) of CRISTA-NF, following e.g. von Clarmann (2006). This ensures that the CLaMS data, like the a priori data used for comparison in Weigel et al. (2010), are comparable to the CRISTA-NF retrieval results in terms of resolution and a priori influence.

\section{Results and comparisons}

\subsection{The AMMA flight on 29 July 2006}

This work focuses on the AMMA flight on 29 July 2006, which took place over Italy and the Mediterranean Sea. The flight took place in the morning between about 06:15 and 09:15 UTC. At this time the pressure differences over the whole Mediterranean area were rather small, with a high pressure system south of Italy at the coast of Africa. On 30 July 2006, 00:00 UTC a low pressure system has developed over southern Italy and a trough is situated northwest of it over Italy and the Adriatic Sea ${ }^{1}$. Figure 1 shows the $\mathrm{H}_{2} \mathrm{O}$ and $\mathrm{O}_{3}$ distributions on the $350 \mathrm{~K}$ level from the CLaMS simulation between $10-60^{\circ} \mathrm{N}$ and $60^{\circ} \mathrm{E}-60^{\circ} \mathrm{W}$. The position of the 2 and $4 \mathrm{PVU}$ line is marked on the $350 \mathrm{~K}$ level from the CLaMS simulation. Areas with horizontal wind speed of more than $30 \mathrm{~m} \mathrm{~s}^{-1}$ are marked to show the position of the subtropical jet. Different potential vorticity value are used in the literature to represent the dynamical tropopause, the best choice is in principle dependent on location, isentropic level and season (Kunz et al., 2011). In Fig. 1 the 2 and 4 PVU (potential vorticity units) line from ECMWF are displayed to indicate where the $350 \mathrm{~K}$ level intersects the dynamical tropopause. In this area, the $350 \mathrm{~K}$ level is located partly in the troposphere and partly in the stratosphere: North of the 2 and $4 \mathrm{PVU}$ lines air of stratospheric characteristics, i.e. high $\mathrm{O}_{3}$ and low $\mathrm{H}_{2} \mathrm{O}$ mixing ratios prevail while the $350 \mathrm{~K}$ level is located in the troposphere to the south of both PVU lines.

Over the North Atlantic, Western Europe, and north of the Baltic Peninsula the distance between the 2 and 4 PVU line is large, they are separated by more than $10^{\circ}$ Latitude over parts of the North Atlantic. This indicated Rossby wave breaking which is relevant for the exchange of trace gases. Over the central Mediterranean and east of about $35^{\circ} \mathrm{E}$ the atmosphere is rather undisturbed, the 2 and $4 \mathrm{PVU}$ line are located close to each other. This indicates a sharp transition between the lowermost stratosphere in the north and the troposphere in the south on the $350 \mathrm{~K}$ level. This transition region was crossed twice during the flight over the Mediterranean Sea. The subtropical jet, marked by the $30 \mathrm{~m} \mathrm{~s}^{-1}$ contour line of the ECMWF wind speed, is most often found close to the $4 \mathrm{PVU}$ line. Over the Atlantic it is situated further north at about $45^{\circ} \mathrm{N}$ than over and east of the Mediterranean Sea, where it is at about $35^{\circ}$ to $40^{\circ} \mathrm{N}$. Water vapor mixing ratios of more than $20 \mathrm{ppmV}$ are found nearly everywhere south of the 2 PVU line and at some places between 2 and 4 PVU. North of the $4 \mathrm{PVU}$ line the water vapor mixing ratios are usually lower than $15 \mathrm{ppmV}$. On contrary high $\mathrm{O}_{3}$ mixing ratios (usually above $250 \mathrm{ppbV}$ ) are found north of the $4 \mathrm{PVU}$ line. South of the $2 \mathrm{PVU}$ line the $\mathrm{O}_{3}$ mixing ratios are mostly lower than $200 \mathrm{ppbV}$. Between the 2 and the $4 \mathrm{PVU}$ line intermediate $\mathrm{O}_{3}$ mixing ratios (200-250 ppbV) are found.

The flight track is located over Italy and the central Mediterranean Sea, where the 2 and 4 PVU lines lie close together and where a narrow core of the jet with a wind speed of more than $35 \mathrm{~m} \mathrm{~s}^{-1}$ occurred. The flight track is shown in the lower panel of Fig. 2. Starting in Verona, the

\footnotetext{
${ }^{1}$ UKMO-Bracknell analysis from http://www.wetterzentrale.de/topkarten/fsfaxsem.html
} 

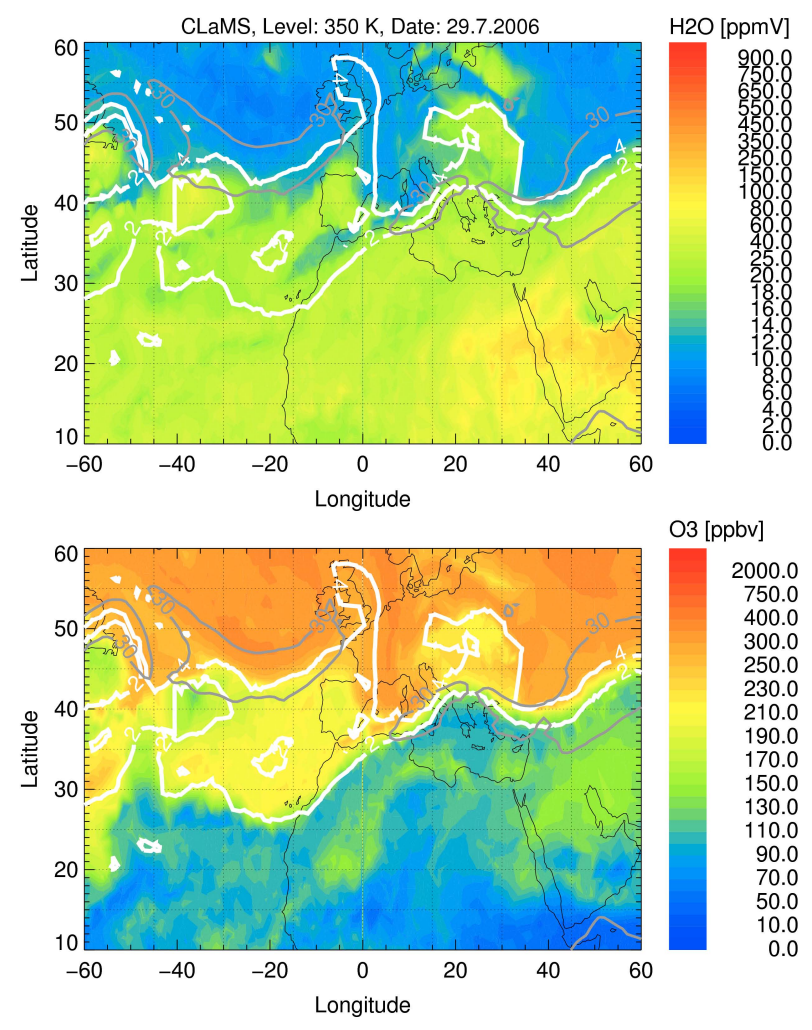

Fig. 1. Map of CLaMS $\mathrm{H}_{2} \mathrm{O}$ and $\mathrm{O}_{3}$ on the $\zeta=350 \mathrm{~K}$ level with 2 and 4 PVU line (white, solid) and horizontal wind speed of $30 \mathrm{~m} \mathrm{~s}^{-1}$ from ECMWF (grey, solid) marking the position of the subtropical jet.

M55-Geophysica flew to the southeast. North of the coast of Sicily, after three short legs towards east, southwest and west the aircraft turned and returned to Verona. A dive down to about $9 \mathrm{~km}$ was performed on the legs towards southwest and west. The view direction of CRISTA-NF is to the right of the aircraft, thus the measurements during the southeastward leg were taken over the Mediterranean Sea. On the way back to Verona they were taken above Italy and the Adriatic Sea. During the turn north of Sicily, CRISTA-NF views towards southeast over Sicily and in northward directions during the dive.

The horizontal position of the tangent point is shown in Fig. 2 color coded with the PAN mixing ratios. PAN is displayed because it contains most structures allowing to compare this figure to the vertical distribution in Fig. 5b. Most structures represent rather vertical than horizontal changes. Due to the nature of the limb measurements the horizontal resolution is much coarser, i.e. in the order of several $100 \mathrm{~km}$ (see Ungermann et al. (2012) for a more detailed discussion).

\subsection{Water vapor and clouds}

Figure 3 shows the water vapor mixing ratios retrieved from CRISTA-NF (panel a), from the CLaMS simulation (panel
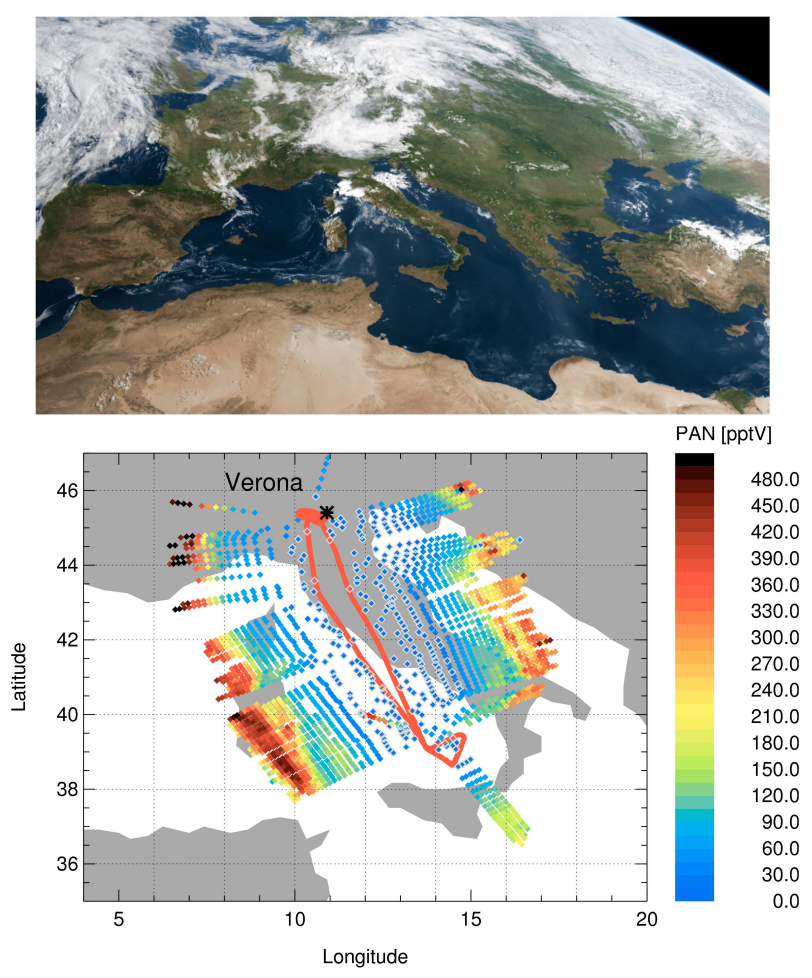

Fig. 2. Upper panel: satellite image of cloud coverage on 29 July 2006, 08:00 UTC, true color image from MSG SEVIRI data, see Reuter and Pfeifer (2011). Lower panel: flight track (red line) and approximated horizontal measurement positions color coded with the PAN mixing ratios as retrieved for the AMMA flight on 29 July 2006. Most structures in the PAN distribution rather represent the vertical distribution shown in Fig. 5 b.

b), and from ECMWF (panel c). The ECMWF and CLaMS data are interpolated on the grid shown in Fig. 2 and folded with the AVK to be comparable to the CRISTA-NF data with respect to a priori influence and resolution. As in Weigel et al. (2010), a climatological profile was chosen as a priori for $\mathrm{H}_{2} \mathrm{O}$ in the retrieval to ensure that all variations are a result of the measurements and not influenced by the choice of the a priori value. In addition to the 2 and 4 PVU lines from ECMWF shown in Fig. 1, the 1.5 PVU line is displayed in Fig. 3 and the following vertical cross sections. The 1.5 PVU line does not follow the 2 PVU line with a constant vertical distance but shows an even steeper increase and decrease in altitude at about $40^{\circ} \mathrm{N}(07: 15$ and 08:15 UTC), respectively. The flight altitude and the PVU lines are shown in all panels for better comparison. Black dots show spectra with optical dense conditions usually due to clouds. Large parts of the flight were performed in cloud free air down to an altitude of $8 \mathrm{~km}$ providing excellent conditions for trace gas retrievals. Early in the morning of 29 July 2006 there are few local clouds over Italy. Later, convective clouds are developing especially over the region of Tuscany and the northern Adriatic Sea. The upper panel of Fig. 2 shows the clouds in a 


\section{a) CRISTA-NF}
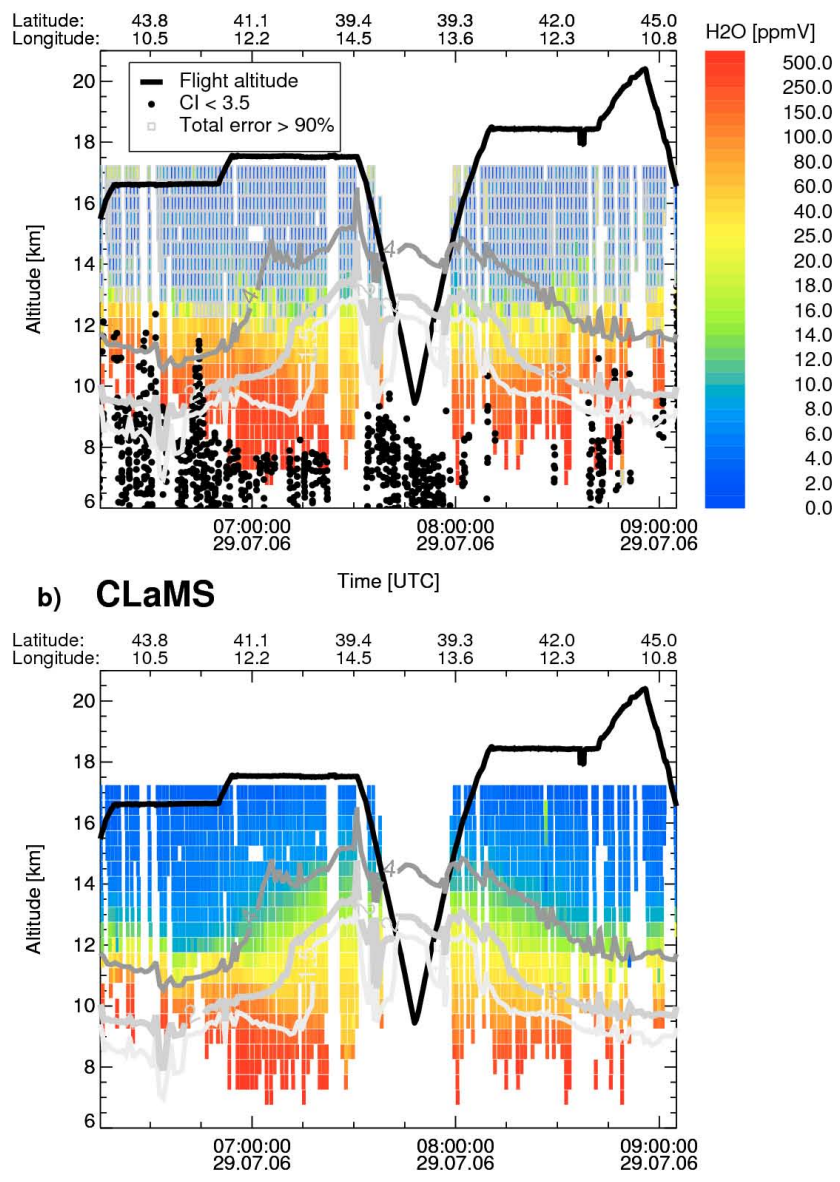

c) ECMWF Time [UTC]

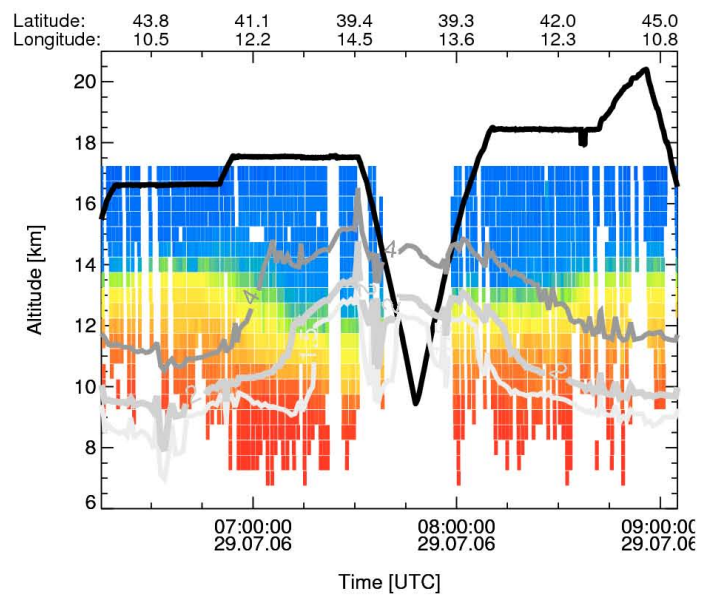

Fig. 3. $\mathrm{H}_{2} \mathrm{O}$ from CRISTA-NF, CLaMS, and ECMWF analysis data. Colour scale shows the $\mathrm{H}_{2} \mathrm{O}$ volume mixing ratio, grey lines show the ECMWF potential vorticity at 1.5, 2 and 4 PVU, black line the flight track, black dots spectra with optical dense conditions, grey diamonds retrieval results with a total error larger than $90 \%$ (with CRISTA-NF $\mathrm{H}_{2} \mathrm{O}$ ). Note nonlinear colour scale. true color image from MSG SEVIRI data (Reuter and Pfeifer, 2011) on 29 July 2006, 08:00 UTC. Clouds above $10 \mathrm{~km}$ are found mainly north of about $43^{\circ} \mathrm{N}$, there also the MSG SEVERI image in the upper panel of Fig. 2 shows patches of clouds.

The detection limit for CRISTA-NF $\mathrm{H}_{2} \mathrm{O}$ is about $15 \mathrm{ppmV}$. Detection limit means that for lower $\mathrm{H}_{2} \mathrm{O}$ mixing ratios the spectral signature of water vapor is not visible in the spectra any more and the combined error exceeds $90 \%$. Here, the detection limit is reached above $12.5 \mathrm{~km}$ altitude for most profiles. An exception are single, remarkably high water vapor values at altitudes of $13-14 \mathrm{~km}$ found in two isolated structures at about 07:00 and 08:30 UTC (at 41-42 ${ }^{\circ} \mathrm{N}$ ) as well as enhanced $\mathrm{H}_{2} \mathrm{O}$ mixing ratios in this altitude in the southernmost part of the flight, i.e. south of about $40^{\circ} \mathrm{N}$ (between 07:15-08:15 UTC). Below $12 \mathrm{~km}$ the $\mathrm{H}_{2} \mathrm{O}$ mixing ratios are lowest in the southernmost part of the flight. One should note, that M55-Geophysika turned around at about 07:45 UTC $\left(39^{\circ} \mathrm{N}\right)$ and CRISTA-NF therefore observes the same structures twice, first looking westward and later looking eastward, compare also Fig. 2.

At 12 to $13 \mathrm{~km}$ altitude, there is an enhanced amount of water vapor mixing ratio in the south of about $40^{\circ} \mathrm{N}$ (between about $07: 15$ to $08: 15$ UTC) in the CLaMS data. This agrees in general with the CRISTA-NF results but the CLaMS $\mathrm{H}_{2} \mathrm{O}$ mixing ratios are somewhat higher and more uniform at these altitudes. The structures of enhanced water vapor seen at about 07:00 and 08:30 UTC in the CRISTANF results above $12 \mathrm{~km}$ are not found in the CLaMS data. Though not resolved in the ClaMS data but observed in PAN (see Sect. 3.4, Fig. 5b) we assume that these structures are real. As in the CRISTA-NF data, there is less water vapor in the southern part of the flight (i.e. south of about $42^{\circ} \mathrm{N}$ ) than in the northern part for the CLaMS data at lower altitudes. But for CLaMS this is the case for altitudes below $10 \mathrm{~km}$ and not up to $12 \mathrm{~km}$ as for CRISTA-NF. Below $12 \mathrm{~km}$ altitude the CLaMS water vapor mixing ratios are lower than the retrieved ones almost everywhere.

The ECMWF $\mathrm{H}_{2} \mathrm{O}$ mixing ratios agree well with the CRISTA-NF results below $12 \mathrm{~km}$. However, the enhanced water vapor values and horizontal structures seen by CRISTA-NF and CLaMS above $12 \mathrm{~km}$ are not found in the ECMWF data. For ECMWF the water vapor is lowest south of about $41^{\circ} \mathrm{N}$ (i.e. between about 07:00 and 08:30 UTC) for altitudes between 12 and $14 \mathrm{~km}$. We cannot explain the difference to the CLaMS data, where the $\mathrm{H}_{2} \mathrm{O}$ mixing ratios are highest in the southern part of the flight in this altitude range. Due to the detection limit for $\mathrm{H}_{2} \mathrm{O}$, the CRISTA-NF $\mathrm{H}_{2} \mathrm{O}$ measurements do not provide enough informations at these altitudes. The distribution of PAN measured by CRISTA-NF (see Sect. 3.4, Fig. 5b) rather agrees with the CLaMS $\mathrm{H}_{2} \mathrm{O}$ distribution than with ECMWF but shows a more complicated structure than the CLaMS $\mathrm{H}_{2} \mathrm{O}$. 


\subsection{Ozone}

The $\mathrm{O}_{3}$ mixing ratios from CRISTA-NF, CLaMS, and ECMWF are shown in Fig. 4. In general, the $\mathrm{O}_{3}$ mixing ratio increases with altitude. In all panels, low, tropospheric $\mathrm{O}_{3}$ mixing ratios are found up to $15 \mathrm{~km}$ altitudes in the middle of the plot, i.e. the southern part of the flight track between about 07:00 and 08:30 UTC. Here, also the 1.5, 2 and 4 PVU lines from ECMWF are found about $2-3 \mathrm{~km}$ higher than in the northern part of the flight (north of about $41-42^{\circ} \mathrm{N}$, i.e. before 07:00 and after 08:30 UTC). The altitudes, shape and absolute $\mathrm{O}_{3}$ mixing ratios differ between the different data sets. It is important to note that the low ozone mixing ratios at altitudes up to $13.5-16 \mathrm{~km}$ are not part of an enclosed feature. The aircraft is turning before 08:00 UTC, measuring the same structure a second time. This time, the viewing direction is toward the northeast instead of southwest.

For the CRISTA-NF data (Fig. 4a) $\mathrm{O}_{3}$ mixing ratios lower than $200 \mathrm{ppbV}$ are found up to an altitude of $16 \mathrm{~km}$ in the southern part of the flight track (south of about $41-42^{\circ} \mathrm{N}$, i.e. between about 07:00 and 08:30 UTC). There, the vertical gradient between tropospheric and stratospheric $\mathrm{O}_{3}$ mixing ratios is especially steep, whilst it is much smoother in the northern part of the flight track. The vertical gradient is smoothest within two intrusions of air with high, rather stratospheric $\mathrm{O}_{3}$ mixing ratios surrounded by tropospheric air with lower $\mathrm{O}_{3}$ mixing ratios. These structures observed in the $\mathrm{O}_{3}$ mixing ratios are significant compared to the size of the retrieval errors. There are somewhat higher $\mathrm{O}_{3}$ mixing ratios in the first half of the flight than in the second half, but in general the structures are nearly symmetrical in both flight directions. This indicates a structure with several hundred kilometers horizontal extent $(>600 \mathrm{~km})$ perpendicular to the flight track. The horizontal extent along the flight track is about $350 \mathrm{~km}$.

In the first half of the flight, there are large $\mathrm{O}_{3}$ mixing ratios reaching down to below $10 \mathrm{~km}$, at about 06:40 UTC $\left(43.5^{\circ} \mathrm{N}, 11^{\circ} \mathrm{E}\right)$. This is, if at all, only mirrored by a single profile at about 08:50 UTC in the second half of the flight. Another region with enhanced $\mathrm{O}_{3}$ is present directly in the beginning of the flight, down to about $11 \mathrm{~km}$. It is not found in the second half, presumably because the descent of the aircraft started before.

A comparison of the structure found in the $\mathrm{O}_{3}$ in Fig. $4 \mathrm{a}$ to the retrieved water vapor in Fig. 3a shows that the isolated structures of enhanced $\mathrm{H}_{2} \mathrm{O}$ observed at at $41-42^{\circ} \mathrm{N}(07: 00$ and 08:30 UTC) above $12 \mathrm{~km}$ coincide with the base of the intrusion of stratospheric $\mathrm{O}_{3}$.

The vertical $\mathrm{O}_{3}$ distribution from CLaMS (Fig. 4b) has a very similar shape compared to the one measured by CRISTA-NF. $\mathrm{O}_{3}$ with less than $200 \mathrm{ppbV}$ is found up to an altitude of $15.5 \mathrm{~km}$ in the southern part of the flight track and there are also intrusions with enhanced $\mathrm{O}_{3}$ and a smooth transition between low and high $\mathrm{O}_{3}$ mixing ratios in between the southern and the northern part. The absolute $\mathrm{O}_{3}$ values dif- a) CRISTA-NF
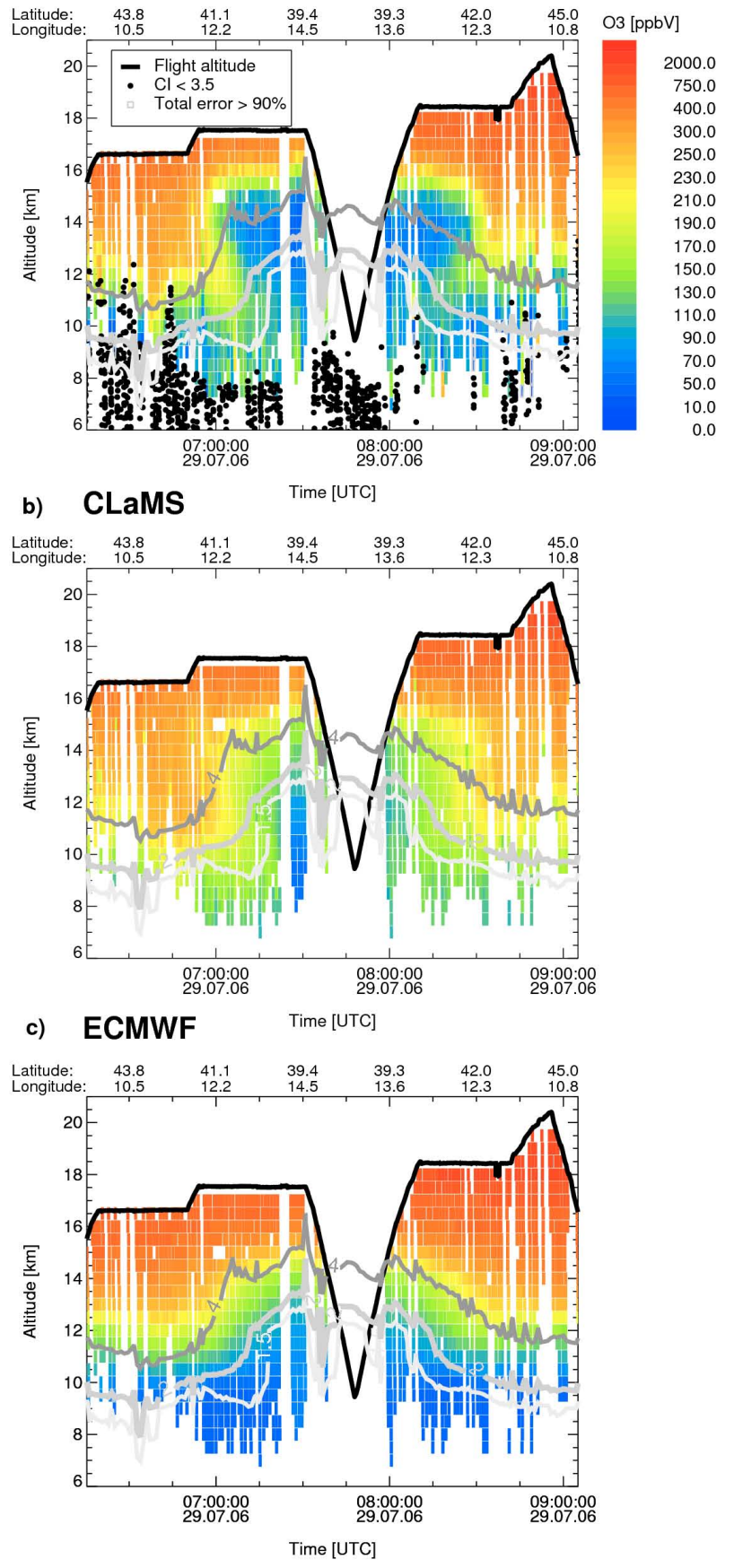

Fig. 4. $\mathrm{O}_{3}$ from CRISTA-NF, CLaMS, and ECMWF analysis data. Colour scale shows the $\mathrm{O}_{3}$ volume mixing ratio, grey lines show the ECMWF potential vorticity at 1.5, 2 and 4 PVU, black line the flight track, black dots spectra with optical dense conditions, grey diamonds retrieval results with a total error larger than $90 \%$ (with CRISTA-NF $\mathrm{O}_{3}$ ). Note nonlinear colour scale.

fer between CLaMS and CRISTA-NF, presumably the modeled $\mathrm{O}_{3}$ mixing ratios are too high in this CLaMS run. In regions of low $\mathrm{O}_{3}$ CRISTA-NF is lower by $50-100 \mathrm{ppbV}$ than 
CLaMS in most places, about $200 \mathrm{ppbV}$ in maximum. At higher altitudes, where higher $\mathrm{O}_{3}$ volume mixing ratios are found, the CRISTA-NF data are about 50-250 ppbV higher than the CLaMS results.

For the ECMWF data (Fig. 4c) the transition is rather smooth and the gradient between low and high $\mathrm{O}_{3}$ about the same along the whole flight path. $\mathrm{O}_{3}$ with less than $200 \mathrm{ppbV}$ is found highest at about $14.5 \mathrm{~km}$. The intrusion of stratospheric air into the troposphere as seen in the CRISTA-NF and CLaMS $\mathrm{O}_{3}$ mixing ratios is not found in the ECMWF data. The transition between stratospheric and tropospheric $\mathrm{O}_{3}$ mixing ratios has not the form of an intrusion in the ECMWF data mainly because air with tropospheric $\mathrm{O}_{3}$ mixing ratios is not found above the $4 \mathrm{PVU}$ line.

\subsection{Other trace gases and temperature}

The CRISTA-NF mixing ratios for $\mathrm{HNO}_{3}$ and PAN as well as temperature are shown in Fig. $5 . \mathrm{HNO}_{3}$ has a similar structure as $\mathrm{O}_{3}$ for the southern part of the flight (south of 41-41 ${ }^{\circ} \mathrm{N}$, i.e. before 07:00 and after 08:30 UTC). Like $\mathrm{O}_{3}$, $\mathrm{HNO}_{3}$ has higher mixing ratios in the stratosphere than in the troposphere. This is clearly visible in the southern part of the flight whilst in the northern part difference in the $\mathrm{HNO}_{3}$ mixing ratios between stratospheric and tropospheric air is found not that obvious and the transition is smooth.

PAN is a tracer originating from the troposphere mainly from aged pollution. The lifetime of PAN is in the order of months in the upper troposphere (Talukdar et al., 1995). Its vertical structure during this flight is similar to the one observed for $\mathrm{H}_{2} \mathrm{O}$. For PAN the detection limit for CRISTA-NF measurements is at about $50 \mathrm{pptV}$. This is usually reached in the lower stratosphere above about $16 \mathrm{~km}$ for most of the profiles. In the southern part, PAN mixing ratios of about $80 \mathrm{pptV}$ are found up to $15.5 \mathrm{~km}$ altitude, in the northern part these values are rather located at $14 \mathrm{~km}$. Enhanced mixing ratios of PAN with over $150 \mathrm{pptV}$ are also found at the same location as the enhanced $\mathrm{H}_{2} \mathrm{O}$ obvious in Fig. 3 at 07:00 and 08:30 UTC (at $41-42^{\circ} \mathrm{N}$ ) between about 12 and $13.5 \mathrm{~km}$. There is an isolated maximum at about $40^{\circ} \mathrm{N}(07: 15$ and 08:15 UTC) in the $14-15 \mathrm{~km}$ region with over $125 \mathrm{pptV}$ PAN surrounded by air with lower PAN mixing ratios of about $90 \mathrm{pptV}$. The distribution is quasi symmetric for the southward and northward flight leg, but the absolute values are higher during the first half of the flight, i.e. with the LOS pointing westward. For both $\mathrm{HNO}_{3}$ and PAN, the observed structures are in most cases significant compared to the combined retrieval error.

Figure $5 \mathrm{c}$ shows the temperature retrieved from CRISTANF observations together with the lapse-rate (or thermal) tropopause calculated from CRISTA-NF measurements following the WMO definition (WMO, 1957). The lowest temperatures for each profile are found at altitudes between 16 and $18 \mathrm{~km}$ during the whole flight. The minimum temperature along the flight path, about $205 \mathrm{~K}$, is located at about a) $\mathrm{HNO} 3$
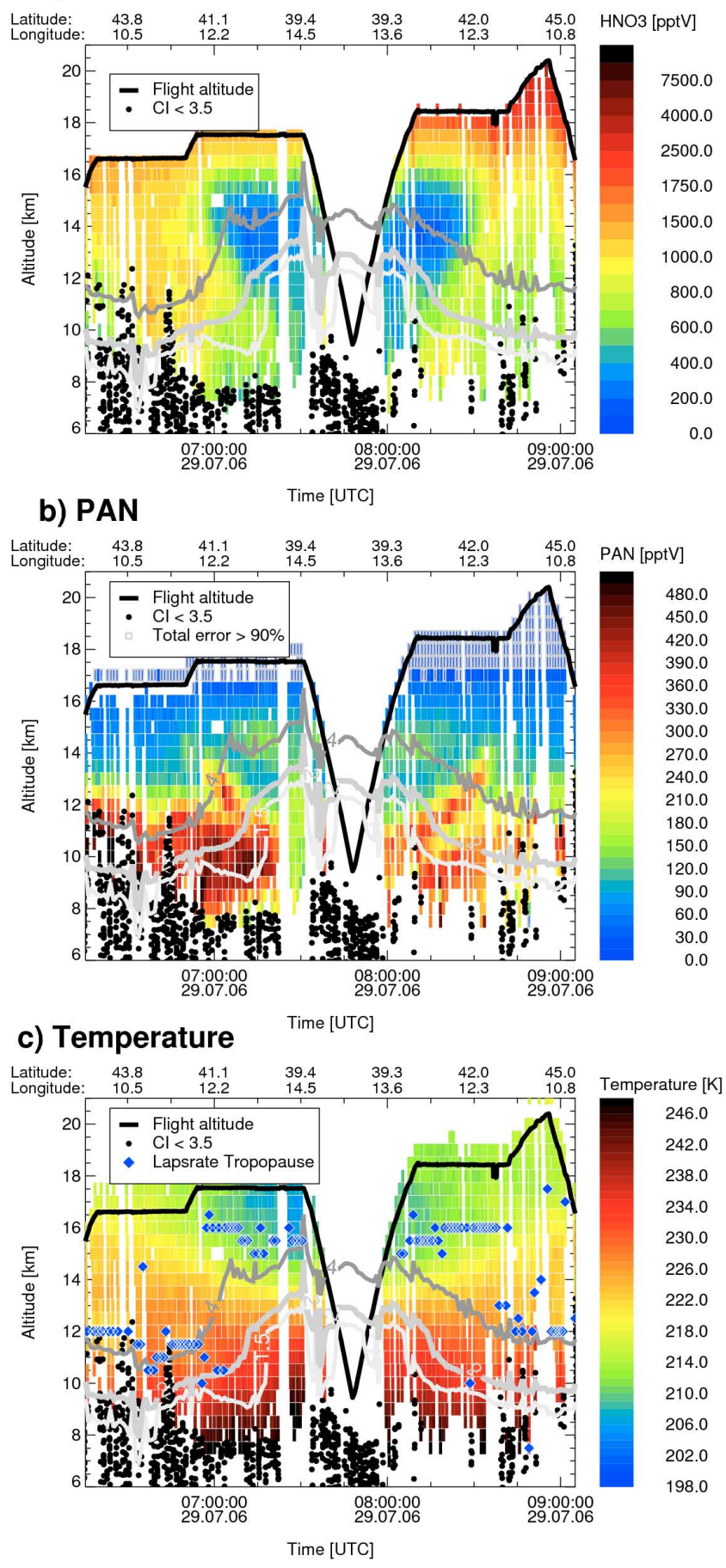

Fig. 5. CRISTA-NF retrieval results for $\mathrm{HNO}_{3}$, PAN, and Temperature. Grey lines show the ECMWF potential vorticity at 1.5, 2 and 4 PVU, black line the flight track, black dots spectra with optical dense conditions, and grey diamonds retrieval results with a total error larger than $90 \%$. Note nonlinear colour scales. 
16 to $17 \mathrm{~km}$ altitude in the southernmost profiles (south of $39.4^{\circ} \mathrm{N}$, at about 07:30 UTC). In this part of the flight also the highest temperatures are observed at an altitude below about $10 \mathrm{~km}$. Thus, the temperature gradient is steeper in the southern part, as expected for air masses of tropical origin. In the northernmost part of the flight, a local minimum can be seen at a altitude of about 12 to $12.5 \mathrm{~km}$.

In summary the trace gases retrieved from CRISTA-NF measurements show a transition from stratospheric to tropospheric characteristics between about 10 and $15 \mathrm{~km}$ altitude at the position where the height of the thermal and dynamical tropopause increases and the subtropical jet is located. This transition is not as clear in the ECMWF data and does not reach as high up as seen in the measurements. The shape and position of the vertical $\mathrm{O}_{3}$ distribution is reproduced well in the CLaMS simulation although the tropospheric $\mathrm{O}_{3}$ mixing ratios are not as low as the ones observed by CRISTA-NF.

\section{Discussion}

The detailed observation of the transition between stratospheric and tropospheric air at the subtropical jet raises the questions where the observed air masses originate from, whether mixing occurs between them and what kind of structure is observed.

\subsection{Where do the observed air masses originate from?}

To gain further insight into the origin and the fate of the air masses detected during the flight trajectories are calculated with CLaMS. Figure 6a shows a map of 10 days backward trajectories of air parcels arriving at all CRISTA-NF grid positions between 350 and $360 \mathrm{~K} \zeta$. Figure $6 \mathrm{~b}$ shows the vertical progression of the trajectories on $\zeta$ levels. For $\zeta$ between 350 and $360 \mathrm{~K}$ relatively low $\mathrm{O}_{3}$ values are found only in the southern part of the flight. All trajectories decent from $\zeta$ levels between 356 and $371 \mathrm{~K}$. The ones with higher $\mathrm{O}_{3}$ mixing ratios originate on average from higher $\zeta$ levels. The trajectory map reveals that nearly all air parcels with low $\mathrm{O}_{3}$ volume mixing ratios lower than $200 \mathrm{ppbV}$ originate from the region around the Asian monsoon anticyclone. In contrast, about all trajectories arriving at the northern part of the flight track with $\mathrm{O}_{3}$ values higher than $200 \mathrm{ppbV}$ come from westerly directions along the subtropical jet.

These pathways agree well with the trajectory calculations by Lelieveld et al. (2002) during the Mediterranean Intensive Oxidant Study (MINOS) in August 2001 for the upper troposphere. The low $\mathrm{O}_{3}$ and $\mathrm{HNO}_{3}$ mixing ratios along with high PAN mixing ratios in the southern part of the flight also correspond well to the ACE-FTS observations of low $\mathrm{O}_{3}$ and $\mathrm{HNO}_{3}$ and high mixing ratios of tropospheric species within the Indian monsoon anticyclone (Park et al., 2008). They observed a strong isolation of the air within this anticyclone. Air influence by the Indian monsoon is also found by Barret et
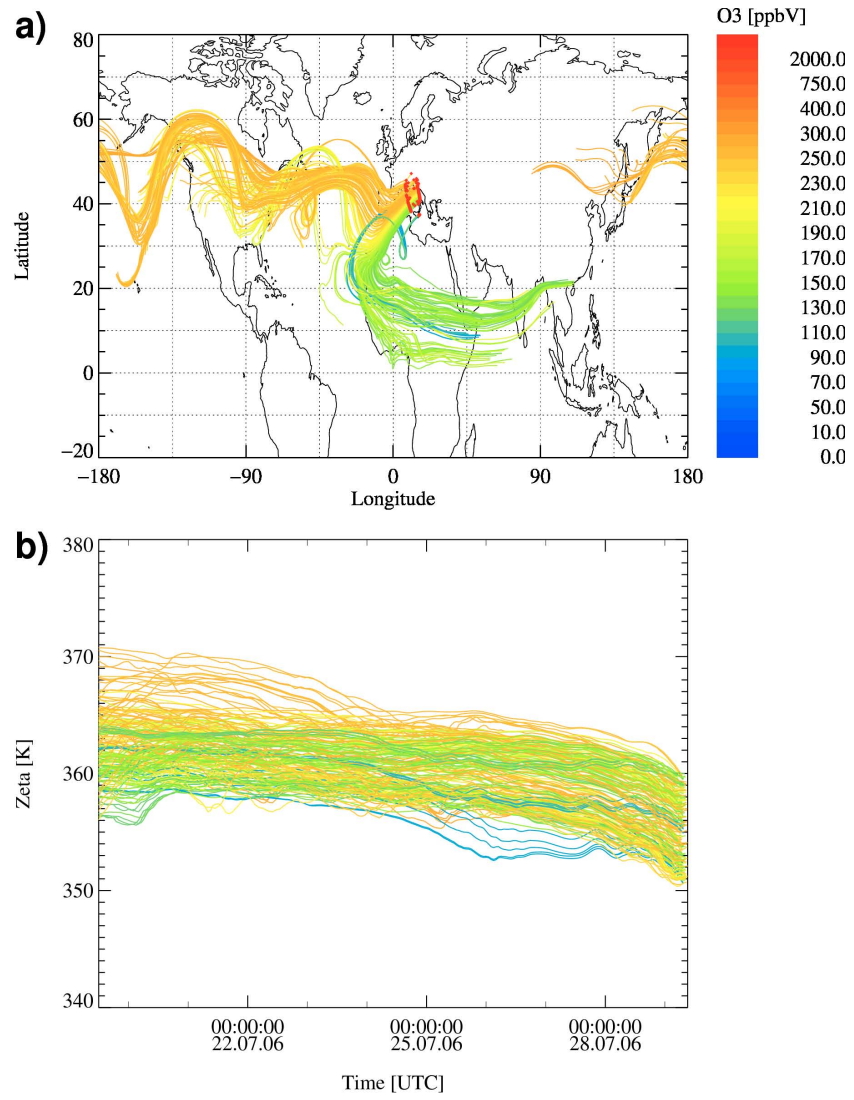

Fig. 6. Panel (a): Map with 10 day backward trajectories from CLaMS starting at the CRISTA-NF grid positions between 350 and $360 \mathrm{~K} \zeta$. Color coding shows the CLaMS $\mathrm{O}_{3}$ on the CRISTA-NF grid (without filtering) during the flight on 29 July 2006. The measurement positions are marked with red diamonds. The vertical position of the $350 \mathrm{~K} \zeta$ level is marked in Fig. 8b. Panel (b): Vertical position of the backward trajectories on $\zeta$ levels.

al. (2008) in MLS CO measurements over the Mediterranean Sea in July 2006 and by Lelieveld et al. (2002) in August 2001, where pollution originating from the Asian monsoon anticyclone is observed close to the tropopause.

To get a deeper insight on the vertical distribution of the observed trace gases, Fig. 7 shows scatter plots of $\mathrm{O}_{3}$ and PAN versus potential temperature calculated from CRISTA-NF temperature measurements and ECMWF analysis pressure. The altitude where the data is observed is color coded. For a potential temperature above about $400 \mathrm{~K}$, $\mathrm{O}_{3}$ increases strong and approximately linearly, as expected for stratospheric air. These values are found at altitudes of $16 \mathrm{~km}$ or higher. Below $400 \mathrm{~K}$ the spread of observed $\mathrm{O}_{3}$ mixing ratios is wider. At $370 \mathrm{~K}$ both tropospheric mixing ratios lower than $100 \mathrm{ppbV}$ and mixing ratios influenced by stratospheric air up to $300 \mathrm{ppbV}$ occur. Their altitude varies between up to $16 \mathrm{~km}$ for the tropospheric mixing ratios and about $14 \mathrm{~km}$ for rather stratospheric mixing ratios. This shows, that during these measurements the maximum 
a)

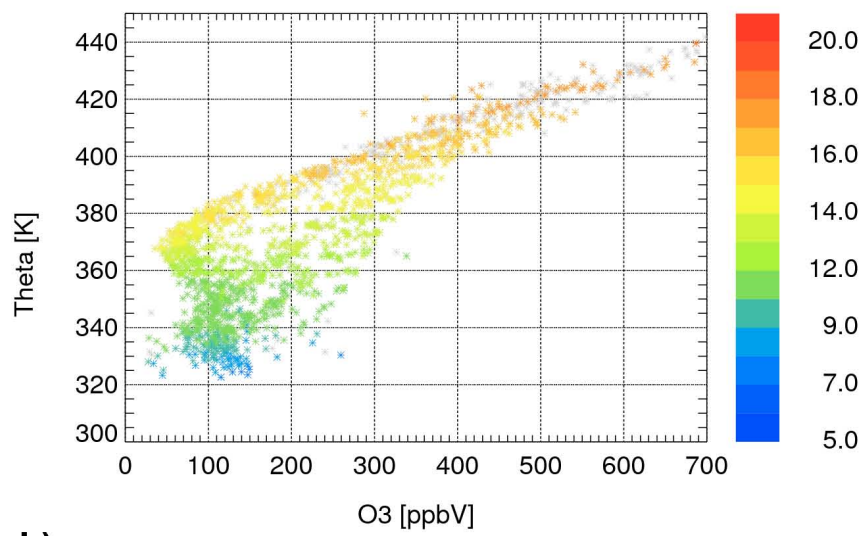

b)

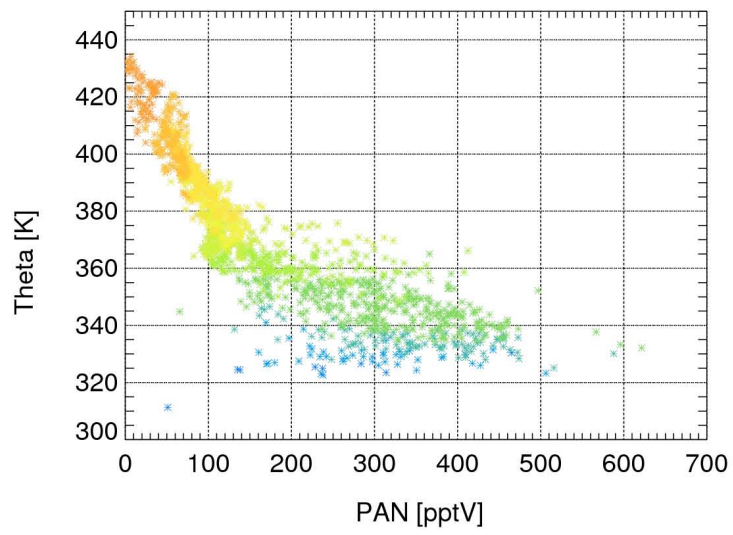

c)

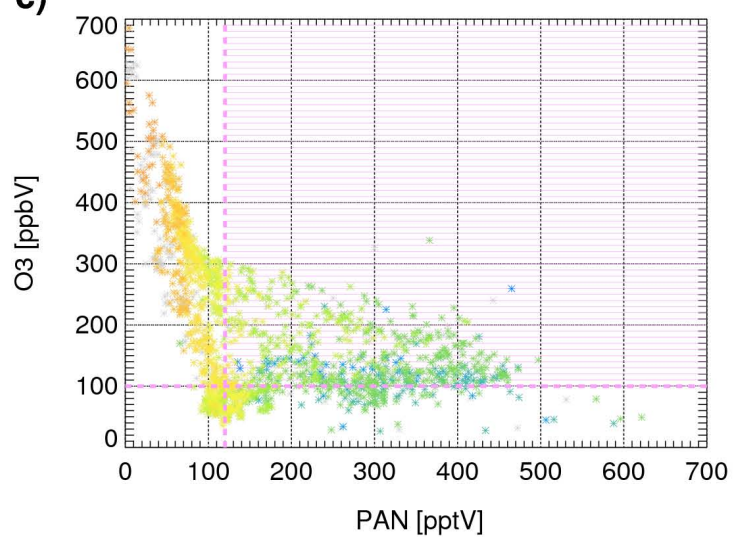

Fig. 7. (a, b) Scatter plot of CRISTA-NF $\mathrm{O}_{3}$ (a) and PAN (b) against potential temperature. Color scales display the altitude of the measured mixing ratios, grey stars show values, with a vertical resolution coarser then $3 \mathrm{~km}$. (c) Scatter plot of CRISTA-NF O $\mathrm{O}_{3}$ and PAN. Pink line shading indicates mixing identified through $\mathrm{O}_{3}$ mixing ratios above $100 \mathrm{ppbV}$ at the same time as PAN mixing ratios above $120 \mathrm{pptV}$.

altitude where tropospheric mixing ratios where observed was higher than the minimum altitudes where stratospheric mixing ratios were observed. The reasons are, that the height of the tropopause varies along the flight track and transport processes between stratosphere and troposphere occur, as it can be expected near the subtropical jet (e.g. Gettelman et al., 2011). The distribution of PAN versus potential temperture differs from the one of $\mathrm{O}_{3}$. The main source of PAN is in the troposphere. Therefore the highest PAN mixing ratios are found below $350 \mathrm{~K}$ and $12 \mathrm{~km}$. The more variable, tropospheric PAN mixing ratios are found up to $380 \mathrm{~K}$. Above $380 \mathrm{~K}$ PAN mixing ratios decrease linearly with increasing potential temperature.

\subsection{Do the observed air masses mix?}

As shown in Fig. 7, the vertical gradients of stratospheric and tropospheric trace gases like $\mathrm{O}_{3}$ have the opposite sign as the gradients of tropospheric trace gases. Therefore, mixing at the tropopause is often identified by tracer-tracer correlations, especially for in situ measurements, e.g. Hoor et al. (2002) and Pan et al. (2004). Hegglin (2010) used tracertracer correlations to identify the extra-tropical transition layer (exTL), a layer with mixed tropospheric and stratospheric air, from ACE-FTS measurements.

The CRISTA-NF observations of PAN are of better quality than the $\mathrm{H}_{2} \mathrm{O}$ observations due to their lower instrumental error and detection limit. In addition to dynamical processes, the transport of $\mathrm{H}_{2} \mathrm{O}$ between the troposphere and the stratosphere is influenced by microphysical processes in connection with clouds, like condensation, evaporation, freezing, and sublimation. Therefore PAN is a better tracer for the mixing of tropospheric and stratospheric air masses. Hence, PAN is used here as tropospheric trace gas for the tracer-tracer correlation with $\mathrm{O}_{3}$ (Fig. 7c). Between the low PAN and high $\mathrm{O}_{3}$ values above $14 \mathrm{~km}$ and the high PAN and low $\mathrm{O}_{3}$ below $13 \mathrm{~km}$ there are intermediate values found between about 10 and $14 \mathrm{~km}$. Such measurements with more than $100 \mathrm{ppbV}$ $\mathrm{O}_{3}$ and simultaneously more than $120 \mathrm{pptV}$ PAN indicate mixing between tropospheric and stratospheric air and are marked with pink rectangles in Fig. 8. Like Hegglin (2010), we use $100 \mathrm{ppbV}$ as the threshold value for tropospheric $\mathrm{O}_{3}$. On the contrary, according to Fig. $7 \mathrm{a} \mathrm{O}_{3}$ mixing ratios up to $160 \mathrm{ppbV}$ are observed for the lowest potential temperatures and altitudes.

The altitudes where intermediate $\mathrm{PAN}$ and $\mathrm{O}_{3}$ mixing ratios occur, indicate a layer about $4 \mathrm{~km}$ wide with mixing between tropospheric and lowermost stratospheric air. It is similar to the one found by Pan et al. (2007) in connection with a tropopause fold on the cyclonic side of the polar jet in December 2005, using in situ measurements. Pan et al. (2007) observed a depth of the mixed air up to $5 \mathrm{~km}$ with rather low $\mathrm{O}_{3}$ values with $100 \mathrm{ppbV}$ also within the mixed air. For the CRISTA-NF measurements during the flight on 29 July the $\mathrm{O}_{3}$ mixing ratios within the mixed air is significantly higher (from 100 up to $300 \mathrm{ppbV}$ ). The observed differences in $\mathrm{O}_{3}$ mixing ratios can probably be explained because Pan et al. (2007) observed a tropopause fold with a larger horizontal extend and their measurements took place 


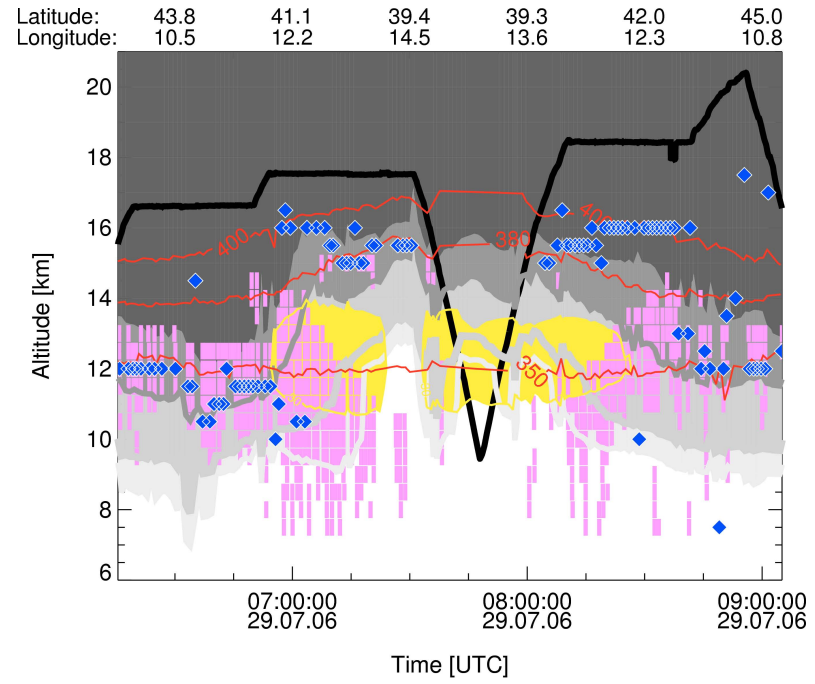

Fig. 8. Grey shadings show the ECMWF potential vorticity at 1.5, 2, 4 and 6 PVU, black line the flight track. Red contour show $\zeta$-level from CLaMS, blue diamonds show the thermal tropopause from CRISTA-NF measurements, and the filled yellow contour shows $30 \mathrm{~m} \mathrm{~s}^{-1}$ the horizontal wind speed from ECMWF. Pink rectangles show positions, where the tracer-tracer correlation in Fig. 7c indicates mixing.

in December 2005, when the $\mathrm{O}_{3}$ was relatively low in the lowermost stratosphere due to its seasonal cycle.

\subsubsection{How does the resolution of CRISTA-NF influence the observations?}

Due to the limb viewing geometry the measurements of CRISTA-NF provide an integrated information along the lines of sight. Along the flight path CRISTA-NF measurements have a relatively high horizontal resolution compared to the coarser horizontal resolution perpendicular to the flight path, along the line of sight. Therefore, it certainly helped to resolve the observed structure that the flight track was aligned nearly perpendicular to them. For the altitudes where the mixing is observed the vertical resolution of PAN and $\mathrm{O}_{3}$ is in most cases better than $3 \mathrm{~km}$. Values with coarser resolution are marked with grey stars in Fig. 7c. Often, the resolution is better than $2 \mathrm{~km}$ for $\mathrm{O}_{3}$ and $1 \mathrm{~km}$ for PAN.

Unlike in situ measurements, CRISTA-NF provides a quasi-2-D cross sections of the atmosphere. Therefore, no in situ measurements deployed on the M55-Geophysica during this flight would be able to detect these structures without extensive flight maneuvers at lower altitudes, which would require some predictive knowledge of the structure.

Hegglin (2010) argued that for ACE-FTS, which has a similar observation geometry but from space, it is extremely unlikely, that air from lower altitudes than the tangent point is observed along the LOS. Therefore the high values of PAN above $12 \mathrm{~km}$ (Fig. 5) can not be caused by the measurement geometry or the extent of the field of view. It is possible, that the retrieved tropospheric $\mathrm{O}_{3}$ values are increased due to the influence of higher stratospheric $\mathrm{O}_{3}$ above, but these influence should be similar for all values in the same altitude. Hence, horizontal gradients should not be influenced. Because mixed and non mixed air is found within the same altitudes and because the layer with mixed air is wider than $4 \mathrm{~km}$, the observed mixing can not be only an artifact of the resolution.

The limb geometry and the field of view of CRISTA-NF may lead to an overestimation of mixing due to enhanced values of stratospheric trace gases and it can be expected that structures have an even smaller vertical extent than seen by the measurements. For this reason it is not possible to give a quantitative estimate of the mixing between stratospheric and tropospheric air or decide if the intrusion of stratospheric air into the troposphere is reversible or irreversible. This can be facilitated by potential future satellite missions, which can provide a similar sampling and spectral resolution as CRISTA-NF with a global coverage.

We can summarize that the mixed air is observed in the lowermost stratosphere and at the subtropical set. This agrees well with the results of Trickl et al. (2011) from trajectory studies, that a significant amount of stratosphere-troposphere transport does occur along the subtropical jet.

\subsection{What kind of structure is observed?}

To get a better insight in the kind of structure that was observed, Fig. 8 resembles the information obtained from CRISTA-NF, CLaMS and ECMWF along the flight path. The grey shades show the 1.5, 2, 4 and 6 PVU surfaces as taken from the ECMWF data, the black line shows the flight altitude. The position of the subtropical jet is marked by a filled yellow contour line showing the horizontal wind speed from ECMWF, the thermal tropopause by blue diamonds. The lapse-rate tropopause lays at about $11-12 \mathrm{~km}$ in the northern and at about $16 \mathrm{~km}$ in the southern part of the flight. At 07:00 and 08:45 (about $41^{\circ} \mathrm{N}$ and $43^{\circ} \mathrm{N}$ ) there is a jump in the altitude of the thermal tropopause of about $4 \mathrm{~km} . \zeta$-levels from CLaMS are shown by the red contours. The measurements indicating mixed air from Fig. 7c are marked as pink rectangles in Fig. 8.

The dynamical tropopause, often defined as the $2 \mathrm{PVU}$ surface (e.g. Pan et al., 2004), is situated at about $10 \mathrm{~km}$ altitude in the northern part of the flight. During the southern part, the $2 \mathrm{PVU}$ surface is located somewhat higher up, at about $13 \mathrm{~km}$. During most of the flight the lapse-rate tropopause is located above the 4 PVU surface (agreeing well with the findings of Kunz et al., 2009). The vertical and meridional wind speeds in the ECMWF data show that the rise of the $2 \mathrm{PVU}$ surface and the shift in the thermal tropopause from low to high altitudes is located precisely at the center of the subtropical jet. Figure 8 shows where the mixed air identified by the tracer-tracer correlation in Fig. 7c is found. Most of the 
mixed air is located north of the jet: at up to about $13 \mathrm{~km}$ in the lowermost stratosphere (above the 2 PVU line and around the lapse-rate tropopause) and directly at the jet up to about $14.5 \mathrm{~km}$ altitude and $\zeta=380 \mathrm{~K}$.

Shapiro (1980) described tropopause folds as mixing regions characterized by a chemical characterization between troposphere and stratosphere. The 2PVU surface in the ECMWF data is not folded as sharply as one would expect in this case, see e.g. the identification of tropopause folds by Sprenger et al. (2003), but one should remember that the $\mathrm{O}_{3}$ intrusion seen in the CRISTA-NF measurements is not resolved in the ECMWF data, too. Nevertheless, all PVU surfaces shown in Fig. 8 rise at least $2 \mathrm{~km}$, where the $\mathrm{O}_{3}$ intrusion is observed by CRISTA-NF. Also the relatively high $\mathrm{O}_{3}$ values in the northern part of the flight down to below $10 \mathrm{~km}$ concur with decreasing altitudes of the shown PVU surfaces. In the ECMWF $\mathrm{O}_{3}$ (Fig. 4c) no corresponding structure is present. These results indicate that the CRISTA-NF measurements show a detailed cross section through a tropopause fold.

Tropopause folds are suspected to be one of the main mechanisms for cross-tropopause-transport (e.g. Shapiro, 1980 and Seo et al., 2008). Hoor et al. (2002) observed a greater depth of the mixing layer above the extra-tropical tropopause during summer and explained it with transport across the tropopause at the subtropical jet. Mixing between tropospheric and lower stratospheric air is observed to occur often in connection with tropopause folds (e.g. Gettelman et al., 2011 and references therein).

In summary, the results of the AMMA flight on 29 July 2006 show that CRISTA-NF provides detailed measurements in the UTLS. The data obtained agree well with modeled data from CLaMS. CRISTA-NF observations and CLaMS simulations indicate, that a tropopause fold was observed, which was not resolved by the ECMWF operational analysis. This shows, that tropopause folds can occur on smaller scales than resolution of ECMWF data allows to observe. At these small scales we found evidence, that $\mathrm{O}_{3}$ rich stratospheric air enters the troposphere as well as tropospheric air the stratosphere. While the intrusion of stratospheric air was seen in the CLaMS model run presented in this work the transport of tropospheric air to the stratosphere was not found in the CLaMS results. Also other studies show tropospherestratosphere exchange at the subtropical jet. One example is the work of Trickl et al. (2011), where layers with high ozone and low water vapor mixing ratios where observed over Garmisch-Partenkirchen. Based on model simulations the origin of these layers was in some cases found at the subtropical jet over the Atlantic. Our study also emphasizes that PAN, which can be observed in the mid infrared also from space (e.g. Wiegele et al., 2012) can reach the tropopause region. This was also observed by in situ measurements in Roiger et al. (2011). In such cases PAN can be used to identify tropospheric air masses.

\section{Conclusions and outlook}

Utilizing the retrieval setup presented in Weigel et al. (2010) a detailed analysis is performed for the flight on 29 July 2006. CRISTA-NF data provides a detailed, two dimensional insight into the UTLS, measuring trace gases of both tropospheric and stratospheric origin. This allows to observe and analyze mesoscale processes. Better understanding of mesoscale processes has implications for the medium range weather forecast and ozone chemistry (WMO, 2006). A sharp transition between tropospheric and stratospheric air was observed over the Mediterranean Sea, identified by strong gradients in $\mathrm{O}_{3}, \mathrm{HNO}_{3}$, and PAN. The structure was reproduced by CLaMS simulations but was not completely resolved in the ECMWF operational analysis data set.

Most probable, the observed intrusion of stratospheric air into the troposphere is the result of a tropopause fold, which is not well resolved in the ECMWF data. CLaMS simulations made it possible to gain further information about the origin and the fate of the observed air masses. They indicate that the observed air originated on the one hand from the tropopause close to the Asian monsoon anticyclone and on the other hand in the extra-tropical lowermost stratosphere along the subtopical jet. Tracer-tracer correlations between PAN and $\mathrm{O}_{3}$ retrieved from the CRISTA-NF measurements show the presence of mixed tropospheric and stratospheric air.

This emphasizes that vertically high resolved limb soundings are capable to provide a detailed picture of the chemical composition in the UTLS. To investigate the UTLS in such detail on a global scale could help to gain a better understanding of the whole atmosphere. This could be achieved in the future by limb-imaging spectrometers as Imaging spectrometers as the GLObal limb Radiance Imager for the Atmosphere (GLORIA), see e.g. Riese et al., 2005; FriedlVallon et al., 2006). An air-borne version of this instrument, GLORIA-AB (Gimballed Limb Observer for Radiance Imaging of the Atmosphere, airborne version) has been developed for the High Altitude and Long Range Research Aircraft (HALO) and M55-Geophysica aircraft. The instrument has been successfully tested on the M55-Geophysica in December 2011. GLORIA-AB will provide an even better resolved view of such small scale structures (Ungermann et al., 2011). GLORIA-AB serves as a prototype for a next generation satellite-borne limb-imager like the ESA candidate mission PREMIER (PRocesses Exploration through Measurements of Infrared and millimeter-wave Emitted Radiation, ESA, 2012; Ungermann et al., 2010). This instrument can offer the possibility to provide global observations of smalland mesoscale processes and quantify their effect on the total exchange between troposphere and stratosphere. 
Acknowledgements. The AMMA-SCOUT-O3 measurement campaign was facilitated by the European Commission and the EC Integrated Project SCOUT-O3 (505390-GOCE-CT-2004) and AMMA. Based on a French initiative, AMMA was set up by an international scientific group and is currently funded by a large number of agencies. It has been the beneficiary of a major financial contribution from the European Communities Sixth Framework Research Program. Many thanks also to the team and pilots of the Myasishchev Design Bureau for making the M55-Geophysica flights possible under difficult logistic conditions. For providing observation data from HAGAR for retrieval support we like to thank C. M. Volk. We thank M. Reuter for providing the MSG Severi image and F. Azam for her support. Last but not least we like to thank everybody, who provided technical support for the CRISTA-NF measurements and data analysis.

The service charges for this open access publication

have been covered by a Research Centre of the

Helmholtz Association.

Edited by: E. Gerasopoulos

\section{References}

Akritidis, D., Zanis, P., Pytharoulis, I., Mavrakis, A., and Karacostas, Th.: A deep stratospheric intrusion event down to the earth's surface of the megacity of Athens, Meteorol. Atmos. Phys., 109, 9-18, doi:10.1007/s00703-010-0096-6, 2010.

Barret, B., Ricaud, P., Mari, C., Attié, J.-L., Bousserez, N., Josse, B., Le Flochmoën, E., Livesey, N. J., Massart, S., Peuch, V.H., Piacentini, A., Sauvage, B., Thouret, V., and Cammas, J.P.: Transport pathways of CO in the African upper troposphere during the monsoon season: a study based upon the assimilation of spaceborne observations, Atmos. Chem. Phys., 8, 3231-3246, doi:10.5194/acp-8-3231-2008, 2008.

Bovensmann, H., Burrows, J. P., Buchwitz, M., Frerick, J., Noël, S., Rozanov, V. V., Chance, K. V., and Goede, A. P. H.: SCIAMACHY: Mission objectives and measurement modes, J. Atmos. Sci., 56, 127-149, 1999.

Brunner, D., Siegmund, P., May, P. T., Chappel, L., Schiller, C., Müller, R., Peter, T., Fueglistaler, S., MacKenzie, A. R., Fix, A., Schlager, H., Allen, G., Fjaeraa, A. M., Streibel, M., and Harris, N. R. P.: The SCOUT-O3 Darwin Aircraft Campaign: rationale and meteorology, Atmos. Chem. Phys., 9, 93-117, doi:10.5194/acp-9-93-2009, 2009.

Cairo, F., Pommereau, J. P., Law, K. S., Schlager, H., Garnier, A., Fierli, F., Ern, M., Streibel, M., Arabas, S., Borrmann, S., Berthelier, J. J., Blom, C., Christensen, T., D’Amato, F., Di Donfrancesco, G., Deshler, T., Diedhiou, A., Durry, G., Engelsen, O., Goutail, F., Harris, N. R. P., Kerstel, E. R. T., Khaykin, S., Konopka, P., Kylling, A., Larsen, N., Lebel, T., Liu, X., MacKenzie, A. R., Nielsen, J., Oulanowski, A., Parker, D. J., Pelon, J., Polcher, J., Pyle, J. A., Ravegnani, F., Rivière, E. D., Robinson, A. D., Röckmann, T., Schiller, C., Simões, F., Stefanutti, L., Stroh, F., Some, L., Siegmund, P., Sitnikov, N., Vernier, J. P., Volk, C. M., Voigt, C., von Hobe, M., Viciani, S., and Yushkov, V.: An introduction to the SCOUT-AMMA stratospheric aircraft, balloons and sondes campaign in West Africa, August 2006: rationale and roadmap, Atmos. Chem. Phys., 10, 2237-2256, doi:10.5194/acp-10-2237-2010, 2010.

ESA, Report for Mission Selection: PREMIER (2012), SP-1324/3, (3 volume series), European Space Agency, Noordwijk, The Netherlands, 2012.

Fastie, W. G.: Ebert Spectrometer Reflections, Phys. Today, 4, 3743, 1991.

Fischer, H. and Oelhaf, H.: Remote sensing of vertical profiles of atmospheric trace constituents with MIPAS limb-emission spectrometers, Appl. Opt., 35, 2787-2796, 1996.

Friedl-Vallon, F., Riese, M., Maucher, G., Lengel, A., Hase, F., Preusse, P., and Spang, R.: Instrument concept and preliminary performance analysis of GLORIA, Adv. Space Res., 37, 22872291, 2006.

Gettelman, A., Hoor, P., Pan, L. L., Randel, W. J., Hegglin, M. I., and Birner, T.: The extratropical upper troposphere and lower stratosphere, Rev. Geophys., 49, RG3003, doi:10.1029/2011RG000355, 2011.

Gerasopoulos, E., Zanis, P., Papastefanou, C., Zerefos, C. S., Ioannidou, A., and Wernli, H.: A complex case study of down to the surface intrusions of persistent stratospheric air over the Eastern Mediterranean, Atmos. Environ. 40, 4113-4125, 2006.

Grooß, J.-U. and Russell III, James M.: Technical note: A stratospheric climatology for $\mathrm{O}_{3}, \mathrm{H}_{2} \mathrm{O}, \mathrm{CH}_{4}, \mathrm{NO}_{\mathrm{x}}, \mathrm{HCl}$ and $\mathrm{HF}$ derived from HALOE measurements, Atmos. Chem. Phys., 5, 2797-2807, doi:10.5194/acp-5-2797-2005, 2005.

Grossmann, K. U., Offermann, D., Gusev, O., Oberheide, J., Riese, M., and Spang, R.: The CRISTA-2 mission, J. Geophys. Res., 107, 8173, doi:10.1029/2001JD000667, 2002.

Günther, G., Müller, R., von Hobe, M., Stroh, F., Konopka, P., and Volk, C. M.: Quantification of transport across the boundary of the lower stratospheric vortex during Arctic winter 2002/2003, Atmos. Chem. Phys., 8, 3655-3670, doi:10.5194/acp-8-36552008, 2008.

Hegglin, M. I., Gettelman, A., Hoor, P., Krichevsky, R., Manney, G. L., Pan, L. L., Son, S.-W., Stiller, G., Tilmes, S., Walker, K. A., Eyring, V., Shepherd, T. G., Waugh, D., Akiyoshi, H., Añel, J. A., Austin, J., Baumgaertner, A., Bekki, S., Braesicke, P., Brühl, C., Butchart, N., Chipperfield, M., Dameris, M., Dhomse, S., Frith, S., Garny, H., Hardiman, S. C., Jöckel, P., Kinnison, D. E., Lamarque, J. F., Mancini, E.,Michou,M., Morgenstern, O., Nakamura, T., Olivié, D., Pawson, S., Pitari, G., Plummer, D. A., Pyle, J. A., Rozanov, E., Scinocca, J. F., Shibata, K., Smale, D., Teyssèdre, H., Tian, W., and Yamashita, Y.: Multimodel assessment of the upper troposphere and lower stratosphere: Extratropics, J. Geophys. Res., 115, D00M09, doi:10.1029/2010JD013884, 2010.

Hoffmann, L.: Schnelle Spurengasretrieval für das Satellitenexperiment Envisat MIPAS, PhD thesis, University of Wuppertal, 2006.

Hoffmann, L. and Alexander, M. J.: Retrieval of Stratospheric Temperatures from Atmospheric Infrared Sounder Radiance Measurements for Gravity Wave Studies, J. Geophys. Res., 114, D07105, doi:10.1029/2008JD011241, 2009.

Hoffmann, L., Kaufmann, M., Spang, R., Müller, R., Remedios, J. J., Moore, D. P., Volk, C. M., von Clarmann, T., and Riese, M.: Envisat MIPAS measurements of CFC-11: retrieval, validation, and climatology, Atmos. Chem. Phys., 8, 3671-3688, doi:10.5194/acp-8-3671-2008, 2008. 
Hoffmann, L., Weigel, K., Spang, R., Schroeder, S., Arndt, K., Lehmann, C., Kaufmann, M., Ern, M., Preusse, P., Stroh, F., and Riese, M.: CRISTA-NF measurements of water vapor during the SCOUT-O3 Tropical Aircraft Campaign, Adv. Space Res., 43, 74-81, 2009.

Homan, C. D., Volk, C. M., Kuhn, A. C., Werner, A., Baehr, J., Viciani, S., Ulanovski, A., and Ravegnani, F.: Tracer measurements in the tropical tropopause layer during the AMMA/SCOUTO3 aircraft campaign, Atmos. Chem. Phys., 10, 3615-3627, doi:10.5194/acp-10-3615-2010, 2010.

Hoor, P., Fischer, H., Lange, L., Lelieveld, J., and Brunner, D.: Seasonal variations of a mixing layer in the lowermost stratosphere as identified by the $\mathrm{CO}-\mathrm{O}_{3}$ correlation from in situ measurements, J. Geophys. Res., 107, 4044, doi:10.1029/2000JD000289, 2002.

James, R. and Legras, B.: Mixing processes and exchanges in the tropical and the subtropical UT/LS, Atmos. Chem. Phys., 9, 2538, doi:10.5194/acp-9-25-2009, 2009.

Kentarchos, A. S., Roelofs, G. J., and Lelieveld, J.: Model study of a stratospheric intrusion event at lower midlatitudes associated with the development of a cutoff low, J. Geophys. Res., 104, 1717-1727, 1999.

Khosrawi, F., Grooß, J.-U., Müller, R., Konopka, P., Kouker, W., Ruhnke, R., Reddmann, T., and Riese, M.: Intercomparison between Lagrangian and Eulerian simulations of the development of mid-latitude streamers as observed by CRISTA, Atmos. Chem. Phys., 5, 85-95, doi:10.5194/acp-5-85-2005, 2005.

Konopka, P., Günther, G., Müller, R., dos Santos, F. H. S., Schiller, C., Ravegnani, F., Ulanovsky, A., Schlager, H., Volk, C. M., Viciani, S., Pan, L. L., McKenna, D.-S., and Riese, M.: Contribution of mixing to upward transport across the tropical tropopause layer (TTL), Atmos. Chem. Phys., 7, 3285-3308, doi:10.5194/acp-7-3285-2007, 2007.

Krämer, M., Schiller, C., Afchine, A., Bauer, R., Gensch, I., Mangold, A., Schlicht, S., Spelten, N., Sitnikov, N., Borrmann, S., de Reus, M., and Spichtinger, P.: Ice supersaturations and cirrus cloud crystal numbers, Atmos. Chem. Phys., 9, 3505-3522, doi:10.5194/acp-9-3505-2009, 2009.

Kullmann, A., Riese, M., Olschewski, F., Stroh, F., and Grossmann, K.-U.: Cryogenic Infrared Spectrometers and Telescopes for the Atmosphere - New Frontiers, Proc. SPIE, 5570, 423-432, 2004.

Kunz, A., Konopka, P., Müller, R., Pan, L. L., Schiller, C., and Rohrer, F.: High static stability in the mixing layer above the extratropical tropopause, J. Geophys. Res., 114, D16305, doi:10.1029/2009JD011840, 2009.

Kunz, A., Konopka, P., Müller, R., and Pan, L.: Dynamical tropopause based on isentropic potential vorticity gradients, J. Geophys. Res., 116, D01110, doi:10.1029/2010JD014343, 2011.

Lawrence, M. G. and Lelieveld, J.: Atmospheric pollutant outflow from southern Asia: a review, Atmos. Chem. Phys., 10, 1101711096, doi:10.5194/acp-10-11017-2010, 2010.

Lelieveld, J., Berresheim, H., Borrmann, S., Crutzen, P. J., Dentener, F. J., Fischer, H., de Gouw, J., Feichter, J., Flatau, P., Heland, J., Holzinger, R., Korrmann, R., Lawrence, M., Levin, Z., Markowicz, K., Mihalopoulos, N., Minikin, A., Ramanathan, V., de Reus, M., Roelofs, G.-J., Scheeren, H. A., Sciare, J., Schlager, H., Schultz, M., Siegmund, P., Steil, B., Stephanou, E., Stier, P., Traub, M., Williams, J., and Ziereis, H.: Global air pollution crossroads over the Mediterranean, Science, 298, 794-799, 2002.
Manney, G. L., Hegglin, M. I., Daffer, W. H., Santee, M. L., Ray, E. A., Pawson, S., Schwartz, M. J., Boone, C. D., Froidevaux, L., Livesey, N. J., Read, W. G., and Walker, K. A.: Jet characterization in the upper troposphere/lower stratosphere (UTLS): applications to climatology and transport studies, Atmos. Chem. Phys., 11, 6115-6137, doi:10.5194/acp-11-6115-2011, 2011.

McKenna, D. S., Konopka, P., Grooß, J.-U., Günther, G., Müller, R., Spang, R., Offermann, D., and Orsolini, Y.: A new Chemical Lagrangian Model of the Stratosphere (CLaMS) 1. Formulation of advection and mixing, J. Geophys. Res., 107, 4309, doi:10.1029/2000JD000114, 2002a.

McKenna, D. S., Grooß, J.-U., Günther, G., Konopka, P., Müller, R., Carver, G., and Sasano, Y.: A new Chemical Lagrangian Model of the Stratosphere (CLaMS) 2. Formulation of chemistry scheme and initialization, J. Geophys. Res., 107, 4256, doi:10.1029/2000JD000113, 2002b.

Offermann, D., Grossmann, K.-U., Barthol, P., Knieling, P., Riese, M., and Trant, R.: Crypgenic Infrared Spectrometers and Telescopes for the Atmosphere (CRISTA) erxperiment and middle atmosphere variability, J. Geophys. Res., 104, 16311-16325, 1999.

Olsen, M. A., Douglass, A. R., Newman, P. A., Gille, J. C., Nardi, B., Yudin, V. A., Kinnison, D. E., and Khosravi, R.: HIRDLS observations and simulation of a lower stratospheric intrusion of tropical air to high latitudes, Geophys. Res. Lett., 35, L21813, doi:10.1029/2008GL035514, 2008.

Pan, L. L., Randel, W. J., Gary, B. L., Mahoney, M. J., and Hintsa, E. J.: Definitions and sharpness of the extratropical tropopause: A trace gas perspective, J. Geophys. Res., 109, D23103, doi:10.1029/2004JD004982, 2004.

Pan, L. L., Bowman,K. P., Shapiro, M., Randel, W. J., Gao, R. S., Campos, T., Davis, C., Schauffler, S., Ridley, B. A., Wei, J. C., and Barnet, C.: Chemical behavior of the tropopause observed during the Stratosphere-Troposphere Analyses of Regional Transport experiment, J. Geophys. Res., 12, D18110, doi:10.1029/2007JD008645, 2007.

Park, M., Randel, W. J., Emmons, L. K., Bernath, P. F., Walker, K. A., and Boone, C. D.: Chemical isolation in the Asian monsoon anticyclone observed in Atmospheric Chemistry Experiment (ACE-FTS) data, Atmos. Chem. Phys., 8, 757-764, doi:10.5194/acp-8-757-2008, 2008.

Purser, R. J. and Huang, H. L.: Estimating effective data density in a satellite retrieval or and objective analysis, J. Appl. Meteorol., 32, 1092-1107, 1993.

Redelsperger, J.-L., Thorncroft, C. D., Diedhiou, A., Lebel, T., Parker, D. J., and Polcher, J.: African Monsoon Multidisciplinary Analysis, B. Am. Meteor. Soc., 87, 1739-1746, doi:10.5194/acp9-3505-2009, 2006.

Remedios, J. J., Leigh, R. J., Waterfall, A. M., Moore, D. P., Sembhi, H., Parkes, I., Greenhough, J., Chipperfield, M. P., and Hauglustaine, D.: MIPAS reference atmospheres and comparisons to V4.61/V4.62 MIPAS level 2 geophysical data sets, Atmos. Chem. Phys. Discuss., 7, 9973-10017, doi:10.5194/acpd-79973-2007, 2007.

Reuter, M., Pfeifer, S.: Moments from space captured by MSG SEVIRI, Int. J. Remote Sens., 32, 4131-4140, doi:10.1080/01431161.2011.566288, 2011.

Riese, M., Tie, X., Brasseur, G., and Offermann, D.: Threedimensional simulation of stratospheric trace gas distributions measured by CRISTA, J. Geophys. Res., 104, 16419-16435, 
doi:10.1029/1999JD900178, 1999.

Riese, M., Manney, G. L., Oberheide, J., Tie, X., Spang, R., and Kuell, V.: Stratospheric transport by planetary wave mixing as observed during CRISTA-2, J. Geophys. Res., 107, 8179, doi:10.1029/2001JD000629, 2002.

Riese, M., Friedl-Vallon, F., Spang, R., Preusse, P., Schiller, C., Hoffmann, L., Konopka, P., Oelhaf, H., von Clarmann, Th., and Hopfner, M.: GLObal limb Radiance Imager for the Atmosphere (GLORIA): Scientific objectives, Adv. Space Res., 36, 989-995, 2005.

Rodgers, C. D.: Inverse Methods for Atmospheric Sounding: Theory and Practice, World Scientific, 2000.

Roiger, A., Schlager, H., Schäfler, A., Huntrieser, H., Scheibe, M., Aufmhoff, H., Cooper, O. R., Sodemann, H., Stohl, A., Burkhart, J., Lazzara, M., Schiller, C., Law, K. S., and Arnold, F.: Insitu observation of Asian pollution transported into the Arctic lowermost stratosphere, Atmos. Chem. Phys., 11, 10975-10994, doi:10.5194/acp-11-10975-2011, 2011.

Schiller, C., Krämer, M., Afchine, A., Spelten, N., and Sitnikov, N.: Ice water content of Arctic, midlatitude, and tropical cirrus, J. Geophys. Res., 113, D24208, doi:10.1029/2008JD010342, 2008.

Schroeder, S. E., Kullmann, A., Preusse, P., Stroh, F., Weigel, K., Ern, M., Knieling, P., Olschewski, F., Spang, R., and Riese, M.: Radiance calibration of CRISTA-NF, Adv. Space Res., 43, 19101917, 2009.

Seo, K.-H., and Bowman, K. P.: Lagrangian estimate of global stratosphere-troposphere mass exchange, J. Geophys. Res., 107, 4555, doi:10.1029/2002JD002441, 2002.

Shapiro, M. A.: Turbulent mixing within tropopause folds as a mechanism for the exchange of chemical constituents between the stratosphere and troposphere, J. Atmos. Sci., 37, 994-1004, 1980.

Spang, R., Hoffmann, L., Kullmann, A., Olschewski, F., Preusse, P., Knieling, P., Schroeder, S., Stroh, F., Weigel, K., Riese, M.: High resolution limb observations of clouds by the CRISTA-NF experiment during the SCOUT-O3 tropical aircraft campaign, Adv. Space Res., 42, 1765-1775, 2008.

Sprenger, M., Maspoli, M. C., and Wernli, H.: Tropopause folds and cross-tropopause exchange: A global investigation based upon ECMWF analyses for the time period March 2000 to February 2001, J. Geophys. Res., 108, 8518, doi:10.1029/2002JD002587, 2003.

Stefanutti, L., Sokolov, L., Balestri, S., MacKenzie, A. R., and Khattatov, V.: The M-55 Geophysica as a Platform for the Airborne Polar Experiment, J. Atmos. Ocean. Technol., 16, 1303-1312, doi:10.1175/1520-0426, 1999.

Talukdar, R. K., Burkholder, J. B., Schmoltner, A.-M., Roberts, J. M., Wilson, R. R., and Ravishankara, A. R.: Investigation of the loss processes for peroxyacetyl nitrate in the atmosphere: UV photolysis and reaction with OH, J. Geophys. Res., 100, 1416314173, doi:10.1029/95JD00545, 1995.

Tang, Q. and Prather, M. J.: Five blind men and the elephant: what can the NASA Aura ozone measurements tell us about stratosphere-troposphere exchange?, Atmos. Chem. Phys., 12, 2357-2380, doi:10.5194/acp-12-2357-2012, 2012.

Traub, M. and Lelieveld, J.: Cross-tropopause transport over the eastern Mediterranean,J. Geophys. Res., 108, 4712, doi:10.1029/2003JD003754, 2003.
Trickl, T., Bärtsch-Ritter, N., Eisele, H., Furger, M., Mücke, R., Sprenger, M., and Stohl, A.: High-ozone layers in the middle and upper troposphere above Central Europe: potential import from the stratosphere along the subtropical jet stream, Atmos. Chem. Phys., 11, 9343-9366, doi:10.5194/acp-11-9343-2011, 2011.

Ungermann, J., Hoffmann, L., Preusse, P., Kaufmann, M., and Riese, M.: Tomographic retrieval approach for mesoscale gravity wave observations by the PREMIER Infrared Limb-Sounder, Atmos. Meas. Tech., 3, 339-354, doi:10.5194/amt-3-339-2010, 2010.

Ungermann, J., Blank, J., Lotz, J., Leppkes, K., Hoffmann, L., Guggenmoser, T., Kaufmann, M., Preusse, P., Naumann, U., and Riese, M.: A 3-D tomographic retrieval approach with advection compensation for the air-borne limb-imager GLORIA, Atmos. Meas. Tech., 4, 2509-2529, doi:10.5194/amt-4-2509-2011, 2011.

Ungermann, J., Kalicinsky, C., Olschewski, F., Knieling, P., Hoffmann, L., Blank, J., Woiwode, W., Oelhaf, H., Hösen, E., Volk, C. M., Ulanovsky, A., Ravegnani, F., Weigel, K., Stroh, F., and Riese, M.: CRISTA-NF measurements with unprecedented vertical resolution during the RECONCILE aircraft campaign, Atmos. Meas. Tech., 5, 1173-1191, doi:10.5194/amt-5-1173-2012, 2012.

Vogel, B., Konopka, P., Grooß, J.-U., Müller, R., Funke, B., LópezPuertas, M., Reddmann, T., Stiller, G., von Clarmann, T., and Riese, M.: Model simulations of stratospheric ozone loss caused by enhanced mesospheric $\mathrm{NO}_{\mathrm{x}}$ during Arctic Winter 2003/2004, Atmos. Chem. Phys., 8, 5279-5293, doi:10.5194/acp-8-52792008, 2008.

von Clarmann, T.: Validation of remotely sensed profiles of atmospheric state variables: strategies and terminology, Atmos. Chem. Phys., 6, 4311-4320, doi:10.5194/acp-6-4311-2006, 2006.

Waters, J., Froidevaux, L., Harwood, R. S., Jarnot, R. F., Pickett, H. M., Read, W. G., Siegel, P. H., Cofield, R. E., Filipiak, M. J., Flower, D. A., Holden, J. R., Lau, G. K., Livesey, N. J., Manney, G. L., Pumphrey, H. C., Santee, M. L., Wu, D. L., Cuddy, D. T., Lay, R. R., Loo, M. S., Perun, V. S., Schwartz, M. J., Stek, P. C., Thurstans, R. P., Boyles, M. A., Chandra, K. M., Chavez, M. C., Chen, G. S., Chudasama, B. V., Dodge, R., Fuller, R. A., Girard, M. A., Jiang, J. H., Jiang, Y. B., Knosp, B. W., LaBelle, R. C., Lam, J. C., Lee, K. A., Miller, D., Oswald, J. E., Patel, N. C., Pukala, D. M., Quintero, O., Scaff, D. M., Van Snyder, W., Tope, M. C., Wagner, P. A., and Walch, M. J., The Earth Observing System Microwave Limb Sounder (EOS MLS) on the Aura satellite, IEEE Trans. Geosci. Remote Sens., 44, 1075-1092, 2006.

Weigel, K., Riese, M., Hoffmann, L., Hoefer, S., Kalicinsky, C., Knieling, P., Olschewski, F., Preusse, P., Spang, R., Stroh, F., and Volk, C. M.: CRISTA-NF measurements during the AMMASCOUT-O3 aircraft campaign, Atmos. Meas. Tech., 3, 14371455, doi:10.5194/amt-3-1437-2010, 2010.

Wiegele, A., Glatthor, N., Höpfner, M., Grabowski, U., Kellmann, S., Linden, A., Stiller, G., and von Clarmann, T.: Global distributions of $\mathrm{C}_{2} \mathrm{H}_{6}, \mathrm{C}_{2} \mathrm{H}_{2}, \mathrm{HCN}$, and PAN retrieved from MIPAS reduced spectral resolution measurements, Atmos. Meas. Tech., 5, 723-734, doi:10.5194/amt-5-723-2012, 2012.

Werner, A., Volk, C. M., Ivanova, E. V., Wetter, T., Schiller, C., Schlager, H., and Konopka, P.: Quantifying transport into the Arctic lowermost stratosphere, Atmos. Chem. Phys., 10, 11623 11639, doi:10.5194/acp-10-11623-2010, 2010. 
World Meteorological Organization (WMO), Meteorology-A threedimensional science, WMO Bull., 6, 134-138, 1957.
WMO: Scientific assessment of ozone depletion: 2006, Report No. 50, 572 Geneva, Switzerland, 2007. 